IMF Staff Papers

Vol. 48, No. 1

(C) 2001 International Monetary Fund

\title{
A Peek Inside the Black Box: The Monetary Transmission Mechanism in Japan
}

\author{
JAMES MORSINK and TAMIM BAYOUMI*
}

This paper uses vector autoregressions to examine the monetary transmission mechanism in Japan. The empirical results indicate that both monetary policy and banks' balance sheets are important sources of shocks, that banks play a crucial role in transmitting monetary shocks to economic activity, that corporations and households have not been able to substitute borrowing from other sources for a shortfall in bank borrowing, and that business investment is especially sensitive to monetary shocks. We conclude that policy measures to strengthen banks are probably a prerequisite to restoring the effectiveness of the monetary transmission mechanism. [JEL E50, E51]

he mechanism for the transmission of monetary policy changes to real activity - the famous "black box"-is always a subject of lively interest to economists. Many channels have been identified, including interest rates, the exchange rate, inflationary expectations (higher expected inflation lowers the real interest rate), bank lending, balance sheet effects, and wealth effects, but there is little agreement on either their precise workings or their relative importance (see Mishkin, 1995).

When an economy is in a recession, such as Japan is experiencing currently, monetary policy and the channels of monetary transmission receive particular scrutiny. In the case of Japan, two further factors make understanding the trans-

\footnotetext{
${ }^{*}$ The authors would like to thank an anonymous referee and their IMF colleagues for valuable comments, especially Timothy Callen, Charles Collyns, Patricia Reynolds, and participants in an IMF Asia and Pacific Department seminar, and Fritz Pierre-Louis for excellent research assistance.
} 
mission mechanism especially important. First, the Bank of Japan (BOJ) has steadily lowered the overnight call rate-the operating target for monetary policy-to "as low as possible," which turns out to be 0.03 percent given transactions costs. With monetary policy bumping up against the nominal floor on interest rates, and attention shifting to a possible role for quantitative easing, examining the monetary transmission mechanism may provide some insight into the effectiveness of policies in this unusual environment.

Second, the 1990s slump in activity has been accompanied by a banking crisis. A growing body of research focuses on the bank lending channel of the monetary transmission mechanism (see Bernanke and Gertler, 1995; and Kashyap and Stein, 1997). Banks are seen as playing an important independent role in overcoming information problems and other frictions in credit markets, so that some borrowers (small firms, for example) cannot readily find substitutes for bank financing. As a result, changes to banks' ability to lend-either reflecting monetary policy developments or other changes to bank capital and funding - are transmitted to bank-dependent borrowers. As banks play a particularly important role in Japan's financial intermediation, ${ }^{1}$ the banking channel may be of particular significance as a conduit for monetary policy and, given the problems being experienced by the banking sector, as an independent source of real disturbances. ${ }^{2}$

This paper uses vector autoregressions (VARs) to examine the monetary transmission mechanism in Japan. This methodology allows us to place minimal restrictions on how monetary shocks affect the economy, whichgiven the lack of consensus about the workings of the monetary transmission mechanism-is a distinct advantage. In addition, this approach recognizes explicitly the simultaneity between monetary policy and macroeconomic developments, that is, the dependence of monetary policy on other economic variables (the policy reaction function), as well as the dependence of economic variables on monetary policy. The choice of a VAR approach is also inspired by the existence of a large empirical literature using VARs to examine the monetary transmission mechanism in the United States, which focuses primarily on reduced-form relationships between monetary policy and output using a small number of variables (for a survey, see Christiano, Eichenbaum, and Evans, 1999). Compared to that literature, we look in more detail at the mechanics of the monetary transmission mechanism. The closest antecedent to this paper in the U.S. literature is Leeper, Sims, and Zha (1996), which also explores the workings of the transmission mechanism.

\footnotetext{
${ }^{1}$ By contrast, the wealth channel may be relatively unimportant in Japan given the limited ownership of equities by individuals.

${ }^{2}$ Two different views of the banking crisis are contained in the literature. Krugman (1998) argues that bank weakness has had little impact on the effectiveness of monetary policy as impaired banks tend to lend too much, not too little. By contrast, Bayoumi (1999) finds that the negative shocks to bank lending, either autonomous or caused by falling asset prices, provided a major deflationary impetus over the 1990s.
} 


\section{Econometric Methodology and Data}

Our basic model includes economic activity, prices, interest rates, and broad money. ${ }^{3}$ Our measure of economic activity is real private demand (real GDP minus total government spending), because public sector demand is driven primarily by fiscal policy, which is assumed to be exogenous. ${ }^{4}$ We express private demand as a ratio to potential output, because it is widely recognized that potential growth in Japan slowed sharply between the 1980s and the 1990s, and we do not want this phenomenon to influence our results-our focus is the impact of monetary events on the cyclical behavior of real private demand. We use the IMF's measure of potential output, which is based on a Cobb-Douglas production function. (For a discussion of the advantages and disadvantages of this measure, see Bayoumi, 1999.) The price level is given by the natural logarithm of the consumer price index, while real broad money (M2 + CDs) is divided by potential output, so that responses can be easily converted into policy multipliers. ${ }^{5}$ The use of potential output to scale real private demand and real broad money is not critical to the results - estimation using the logarithms of activity and money yielded similar results. ${ }^{6}$

Our measure of the stance of monetary policy in Japan is the (uncollateralized) overnight call rate, the current operating target of policy. Although both the instruments and operating objectives of the Bank of Japan have evolved over time, mostly reflecting the development of financial markets, several authors have noted that monetary policy has consistently laid a strong emphasis on shortterm interest rates. For example, Okina (1993) states that the Bank of Japan's policy "always begins with controlling interest rates in short-term money markets."7 Other recent work on monetary policy in Japan, such as Kwon (1998) and Ogawa (1999), has also focussed on the overnight call rate. Other short-term interest rates, such as the Gensaki (repurchase of government securities) rate, closely track the call rate.

In addition to a constant term and a time trend, the VAR also includes two dummy variables aimed at capturing the short-term shifting of demand seen in the quarter before and the quarter after the introduction of the consumption tax in April 1989 and its increase in April 1997, with each variable designed so that the

\footnotetext{
${ }^{3}$ The inclusion of the real effective exchange rate yields similar results for these variables and plausible results for the exchange rate. Given that Japan-like the U.S. - is a relatively closed economy and that the exchange rate channel is not the focus of this paper, we omit the exchange rate from subsequent models.

${ }^{4} \mathrm{An}$ alternative interpretation is that the multiplier on government spending is unity, a value used in other IMF work (Lipworth and Meredith, 1998), although recent empirical work has pointed to a somewhat lower value (Bayoumi, 1999).

${ }^{5}$ The data sources are provided in Appendix I. Since activity and money are measured as ratios to potential output, prices are in logarithms, and the nominal interest rate is a ratio, a change of 0.01 represents a 1 percentage point change in the relevant variable.

${ }^{6}$ For other recent empirical work using this approach, see Bayoumi (1999).

${ }^{7}$ See also Singleton (1993) and Ueda (1993) in the same volume. Kasa and Popper (1997), who use a structural VAR approach to study the objectives and operating procedures of the BOJ, also conclude that short rates are important.
} 
impacts sum to zero over time. The VAR is estimated with quarterly, seasonallyadjusted data from 1980Q1 to 1998Q3 using two lags-the results are similar when we start the estimation a few years earlier or later, or use different lags.

The VAR is identified using a Choleski decomposition, with the ordering being private demand, prices, the overnight call rate, and broad money. As the reduced-form errors are typically correlated, the Choleski decomposition isolates the underlying structural errors by recursive orthogonalization, with the innovation in the first equation untransformed, the innovation in the second equation taken as orthogonal to the first, and so on. The ordering determines the level of exogeneity of the variables, so current shocks to activity are assumed independent of current shocks to all the other variables in the system, while current shocks to money are assumed to be affected by current shocks to all other variables.

The ordering was chosen on the basis of the speed with which the variables respond to shocks, with output assumed to be the least responsive, followed by prices, then short rates, and finally broad money. Given the time-consuming planning processes involved in setting output and prices, these variables are assumed not to react to contemporaneous shocks to financial variables. The monetary authorities are assumed to set the call rate with information about the contemporaneous behavior of slowly-moving output and prices, but without a full picture of the behavior of quickly-changing financial variables. Broad money-and, in the extended VARs, funding or lending aggregates-are assumed to reflect contemporaneous shocks to output, prices, and monetary policy. Although we did not estimate all possible alternative orderings, the results were similar for some radical re-orderings (in particular, completely reversing the ordering to be money, interest rate, prices, and activity). Alternative orderings are also discussed regularly in the discussion of the extended VARs.

While Choleski decompositions are a common method of identifying a VAR, other methods, which assume two-way contemporaneous feedback between some elements of the VAR, have also been developed. Such methods have been used to help identify monetary VARs of the type we are estimating (using U.S. data), although we did not utilize such an approach for two reasons. First, a survey of the monetary VAR literature by Christiano, Eichenbaum, and Evans (1999) finds considerable agreement about the qualitative effects of monetary policy across a large subset of the identification schemes that have been proposed. Second, the cost of more complex approaches, in which the contemporaneous relationships between variables are more simultaneous, is that the identification scheme becomes more complicated without necessarily becoming less controversial. Given the robustness of our results to relatively radical re-orderings of the underlying variables, we focussed only on Choleski decompositions.

We then extend the VAR in a number of different directions to examine alternative aspects of the monetary transmission mechanism. To analyze the sensitivity of different components of private demand to monetary shocks, we split private demand into its main components: private consumption, business investment, housing investment, and net exports. For each component (say, private consumption), we estimate a VAR with the following ordering: total private demand minus 
the component of interest, the demand component of interest, prices, the overnight call rate, and broad money.

To investigate the role of financial intermediation in the monetary transmission mechanism, we extend the basic VAR by including the main components of private sector funding. Specifically, we add loans received by corporations and individuals from public financial institutions, loans from private financial institutions (essentially bank loans), and funds raised in securities markets. Public financial institutions, such as the Housing Loan Corporation, the Japan Development Bank, and the Finance Corporation for Small Business, support policy objectives by providing subsidized loans. While the supply of public loans is thus partly exogenous, both the demand and supply of public loans also react to shocks to the variables included in our model. We order public loans before securities markets and bank loans on the assumption that bureaucratic processes are generally slower than private sector processes. It turns out that the results are similar for different orderings.

Next, to further examine the role of banks in the monetary transmission mechanism, we incorporate the two main components of bank assets: loans and holdings of securities. Securities holdings are ordered last, reflecting the relative ease with which they can be adjusted. If, as we suspect, shocks to bank assets turn out to be important in causing output variations, how should we think about them, as distinct from interest rate and money shocks? One possibility, suggested by the literature on the credit crunch, is that shocks to bank loans reflect changes in banks' capital strength (see Ito and Sasaki, 1998, and Woo, 1999). For example, an unexpected improvement in bank strength might cause banks to extend more loans. To test this hypothesis, we add a market-based indicator of bank strengthbank stock prices relative to overall stock prices- to the bank credit VAR. ${ }^{8}$

Finally, we estimate a single VAR that we feel captures the key elements of the monetary transmission mechanism. As business investment turns out to be much more sensitive to monetary shocks than other components of private demand, we run the VAR with private demand split into business investment and the remainder. We then include the other basic variables-prices, overnight call rate, and broad money. As our investigation of the transmission channel from the perspectives of both borrowers (private sector funding) and lender (bank assets) revealed the important role played by bank loans to the private sector, we include this variable.

\section{Empirical Results}

\section{Basic Monetary Model}

The basic model, which includes private demand, prices, interest rates, and money, provides four important results relevant to the monetary transmission mechanism: (i) interest rate shocks have significant effects on real private demand, consistent

\footnotetext{
${ }^{8}$ The stock price index for the banking sector from the Tokyo Stock Exchange is available starting in 1983, truncating the sample period. The variable is normalized to unity over the sample period, so that changes have the interpretation of percentage deviations. This variable was ordered last in the VAR, given that market prices generally respond quickly to all types of shocks.
} 
with an important role for monetary policy; (ii) broad money shocks also have significant effects on output, even though interest rates are included in the model, consistent with the idea that nonpolicy monetary shocks are also important in determining economic activity; (iii) much of the effect of interest rate shocks on output is transmitted through broad money; and (iv) base money has no significant impact on output.

The results from the basic model are illustrated through the model's impulse response functions reported in Figure $1 .{ }^{9} \mathrm{An}$ unexpected rise in short-term interest rates causes a statistically significant decline in private demand, which bottoms out after 8-10 quarters. The implied multiplier for the interest rate is minus 0.6 , calculated as the ratio of the fall in output ( 0.3 percent) to a typical interest rate shock $(0.5$ percent $) .{ }^{10} \mathrm{~A}$ broad money shock also causes a significant increase in private demand, with a ¥100 increase in broad money raising real private demand by $¥ 80$. The fact that a money shock has a large impact on economic activity, even when the interest rate is included as a separate variable in the VAR (that is, we control for interest rates), is consistent with the idea that the interest rate channel alone does not fully account for the sources and transmission of monetary shocks in Japan.

The price level responds positively to an interest rate innovation, apparently suggesting that a monetary contraction produces inflation. This latter result is commonly found in the empirical literature on the monetary transmission mechanism in the United States and has been dubbed the "price puzzle." As noted by Sims (1992), the price puzzle could be a consequence of failing to include a rich enough specification of the information available to policymakers. If policymakers can observe variables that contain useful information about future inflation, but those variables are not included in the model, there will be apparently unpredictable changes in interest rates that are actually systematic responses to information implying that inflation is on the way. ${ }^{11}$

Interest rates rise in response to price shocks but are relatively insensitive to private demand shocks, consistent with the BOJ's emphasis on price stability. The fact that interest rates do not respond to real private demand innovations, but private demand responds negatively to interest rate innovations, suggests that simultaneity in the determination of these variables may not be a serious problem. The combination of positive interest rate and output responses to broad money innovations could reflect the predominance of favorable real shocks that are not fully accommodated. Another possible explanation is that money (supply) shocks

${ }^{9}$ Detailed results for this VAR and the others reported in the paper are contained in Appendix II, including two-standard-error bands around the impulse responses. The analytic asymptotic standard errors are computed according to the formula given in Hamilton (1994, page 339). Similar results were obtained using Monte Carlo standard errors.

${ }^{10}$ This multiplier is similar to that obtained by Bayoumi (1999), who uses a VAR methodology with a different set of variables, although only about half of that obtained by Lipworth and Meredith (1998), who use the Japan block of the IMF's MULTIMOD model, and at the lower end of the range of estimates from large econometric models presented by Krugman (1998).

${ }^{11}$ The introduction of commodity prices reduces this source of bias in empirical work on the United States (see, for example, Christiano, Eichenbaum, and Evans, 1996). However, neither commodity prices nor stock prices resolved the price puzzle in Japan. 
Figure 1. Japan: Impulse Response Functions for the Basic Model

(Response to one S.D. innovations)
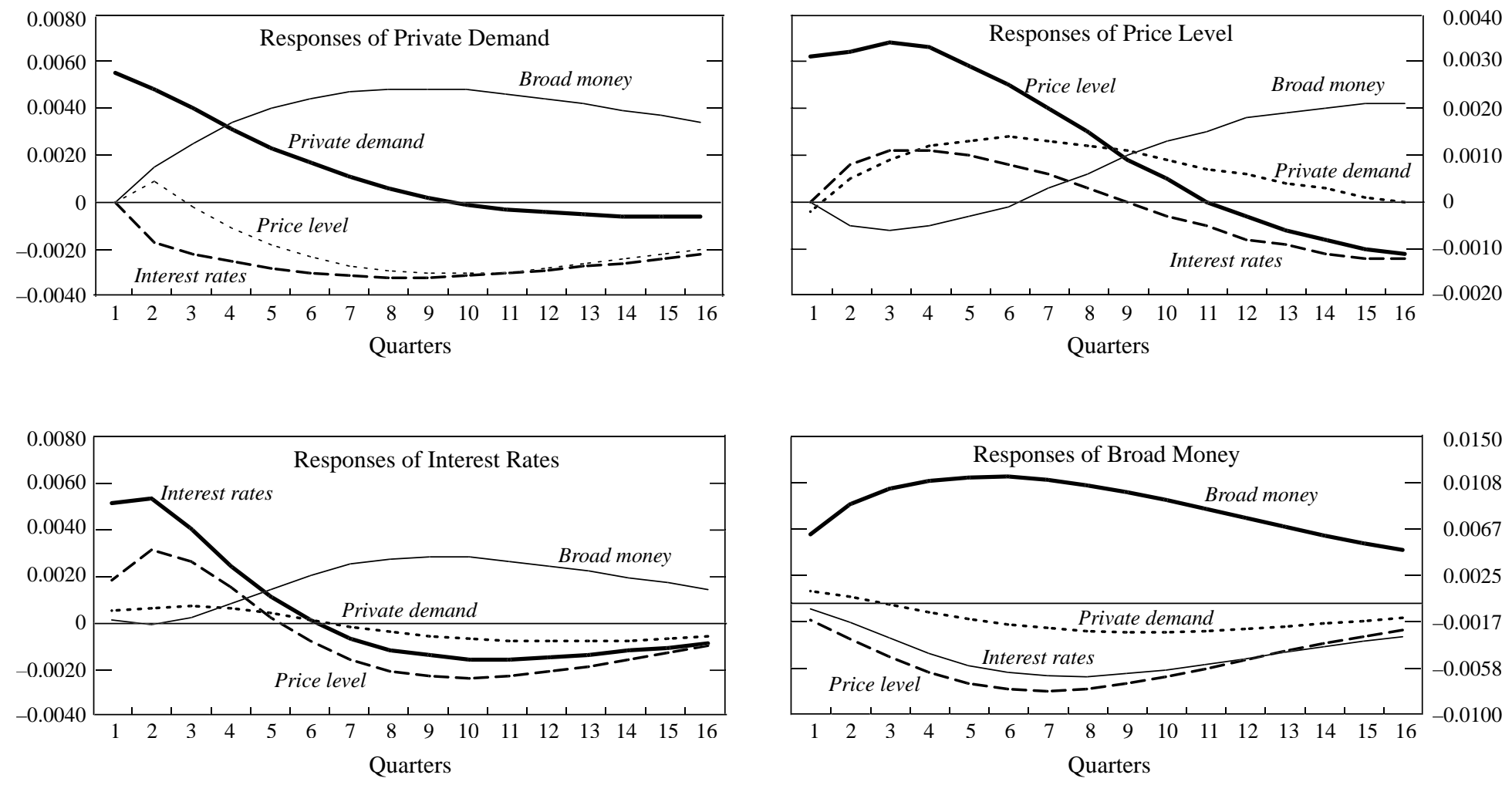

Source: Authors' calculations. 
are indicative of future inflation, consistent with the price level's positive response to money shocks. Finally, broad money responds negatively to interest rate innovations (tighter monetary policy) and price level innovations (adverse aggregate supply shocks), and positively (but not significantly) to real private demand innovations, consistent with standard views on the behavior of money demand.

To get an idea of the share of the fluctuations in a given variable that are caused by different shocks, we calculate variance decompositions for each variable at forecast horizons of one through four years (Table 1). The second column in each sub-table gives the forecast error of the variable for each forecast horizon. ${ }^{12}$ The remaining columns give the percentage of the variance due to each shock-each row adds up to 100 . The results indicate that, after two years, monetary factors (both interest rate and broad money shocks) account for over half of the fluctuation in private demand, while own shocks account for less than one third of such variance - a significantly lower value than for any other variable in the VAR. Interest rate innovations alone account for about 20 percent of the variance in private demand after two years-similar to empirical results for the U.S. economy. In short, monetary factors appear to be very important determinants of fluctuations in economic activity.

The significant influence of broad money on private demand suggests that it may be an important channel for transmitting changes in interest rates. To examine this issue, we reran the VAR with broad money exogenized, i.e., the lagged values of broad money are treated as exogenous variables in a smaller VAR involving private demand, prices, and the interest rate (Appendix III). Such a procedure generates a VAR identical to the original, except that it blocks off any responses within the VAR which pass through the broad money variable, hence comparisons of the responses of the two models provide a measure of the importance of money in the transmission mechanism. Comparing the two impulse responses of real private demand to interest rate innovations (Figure 2), it is clear that the money supply is an important conduit for the impact of interest rates on real activity. 13

To examine the interest rate channel more closely, we extended the VAR by adding the interest rate on new bank loans (ordered last). We find that the lending rate responds immediately and strongly to an unexpected change in the overnight call rate. In turn, private demand and broad money respond negatively and significantly to lending rate shocks. These results point to an interest rate channel that originates in the policy interest rate and goes through the bank lending rate and bank balance sheets (including broad money) to affect private demand.

Thus far, we have assumed that monetary policy only acts through interest rates, not through the quantity of high powered money ("quantitative easing"). To address the issue of whether base money is also important for aggregate demand when

${ }^{12}$ The source of the forecast error is the variation in current and future values of the innovations to each variable in the VAR.

${ }^{13}$ Since broad money is roughly equivalent to the liabilities of the banking system, this result also suggests that banks in particular may play an important role in the transmission mechanism. This is further supported by other results (not reported for the sake of brevity) in which M2 was divided into M1 and quasi-money. The results from this model indicate that it is quasi-money (time and savings deposits) rather than M1 (currency and demand deposits) that primarily affects real demand. 
Table 1. Japan: Variance Decompositions for the Basic Monetary Model (In percent)

\begin{tabular}{rccccr}
\multicolumn{7}{c}{ Variance Decomposition of Private Demand } \\
Quarter & $\begin{array}{c}\text { Forecast } \\
\text { Error }\end{array}$ & $\begin{array}{c}\text { Private } \\
\text { Demand }\end{array}$ & $\begin{array}{c}\text { Price } \\
\text { Level }\end{array}$ & $\begin{array}{c}\text { Interest } \\
\text { Rates }\end{array}$ & $\begin{array}{r}\text { Broad } \\
\text { Money }\end{array}$ \\
4 & 1.1 & 68.6 & 1.8 & 12.2 & 17.3 \\
8 & 1.6 & 33.6 & 10.0 & 18.9 & 37.6 \\
12 & 2.1 & 21.0 & 14.6 & 20.6 & 43.9 \\
16 & 2.3 & 17.1 & 15.7 & 21.1 & 46.1
\end{tabular}

\begin{tabular}{rccccr}
\multicolumn{7}{c}{ Variance Decomposition of Price Level } \\
Quarter & $\begin{array}{c}\text { Forecast } \\
\text { Error }\end{array}$ & $\begin{array}{c}\text { Private } \\
\text { Demand }\end{array}$ & $\begin{array}{c}\text { Price } \\
\text { Level }\end{array}$ & $\begin{array}{c}\text { Interest } \\
\text { Rates }\end{array}$ & $\begin{array}{r}\text { Broad } \\
\text { Money }\end{array}$ \\
4 & 0.7 & 5.2 & 86.8 & 6.2 & 1.7 \\
8 & 0.9 & 11.8 & 79.8 & 6.6 & 1.8 \\
12 & 1.0 & 13.3 & 69.7 & 6.7 & 10.4 \\
16 & 1.1 & 10.6 & 57.4 & 9.4 & 22.6
\end{tabular}

\begin{tabular}{rccccr}
\multicolumn{5}{c}{ Variance Decomposition of Interest Rates } \\
Quarter & $\begin{array}{c}\text { Forecast } \\
\text { Error }\end{array}$ & $\begin{array}{c}\text { Private } \\
\text { Demand }\end{array}$ & $\begin{array}{c}\text { Price } \\
\text { Level }\end{array}$ & $\begin{array}{c}\text { Interest } \\
\text { Rates }\end{array}$ & $\begin{array}{c}\text { Broad } \\
\text { Money }\end{array}$ \\
\hline 4 & 1.0 & 1.2 & 21.6 & 76.8 & 0.5 \\
8 & 1.1 & 1.2 & 23.1 & 61.0 & 14.7 \\
12 & 1.4 & 2.3 & 27.5 & 46.3 & 23.8 \\
16 & 1.5 & 3.2 & 28.2 & 42.6 & 26.0
\end{tabular}

\begin{tabular}{rccccc}
\multicolumn{7}{c}{ Variance Decomposition of Broad Money } \\
Quarter & $\begin{array}{c}\text { Forecast } \\
\text { Error }\end{array}$ & $\begin{array}{c}\text { Private } \\
\text { Demand }\end{array}$ & $\begin{array}{c}\text { Price } \\
\text { Level }\end{array}$ & $\begin{array}{c}\text { Interest } \\
\text { Rates }\end{array}$ & $\begin{array}{c}\text { Broad } \\
\text { Money }\end{array}$ \\
4 & 2.1 & 0.5 & 16.4 & 7.4 & 75.8 \\
8 & 3.7 & 1.4 & 22.6 & 14.0 & 62.0 \\
12 & 4.4 & 2.2 & 23.3 & 16.2 & 58.3 \\
16 & 4.7 & 2.5 & 22.8 & 16.8 & 57.9
\end{tabular}

Source: Authors' calculations.

interest rates are held constant, we added base money to the basic model. ${ }^{14}$ The impulse response of real demand to base money is small and insignificant-a typical money base shock raises real private demand by less than 0.1 percent. In addition, adding base money has no perceptible impact on either the size or significance of the

\footnotetext{
${ }^{14}$ The equation for base money is ordered second to last (before broad money but after the short-term interest rate to account for the impact of interest rate changes on base money). The results are similar if base money is ordered last.
} 
Figure 2. Japan: Response of Real Private Demand to Interest Rates (Response to one S.D. innovations)

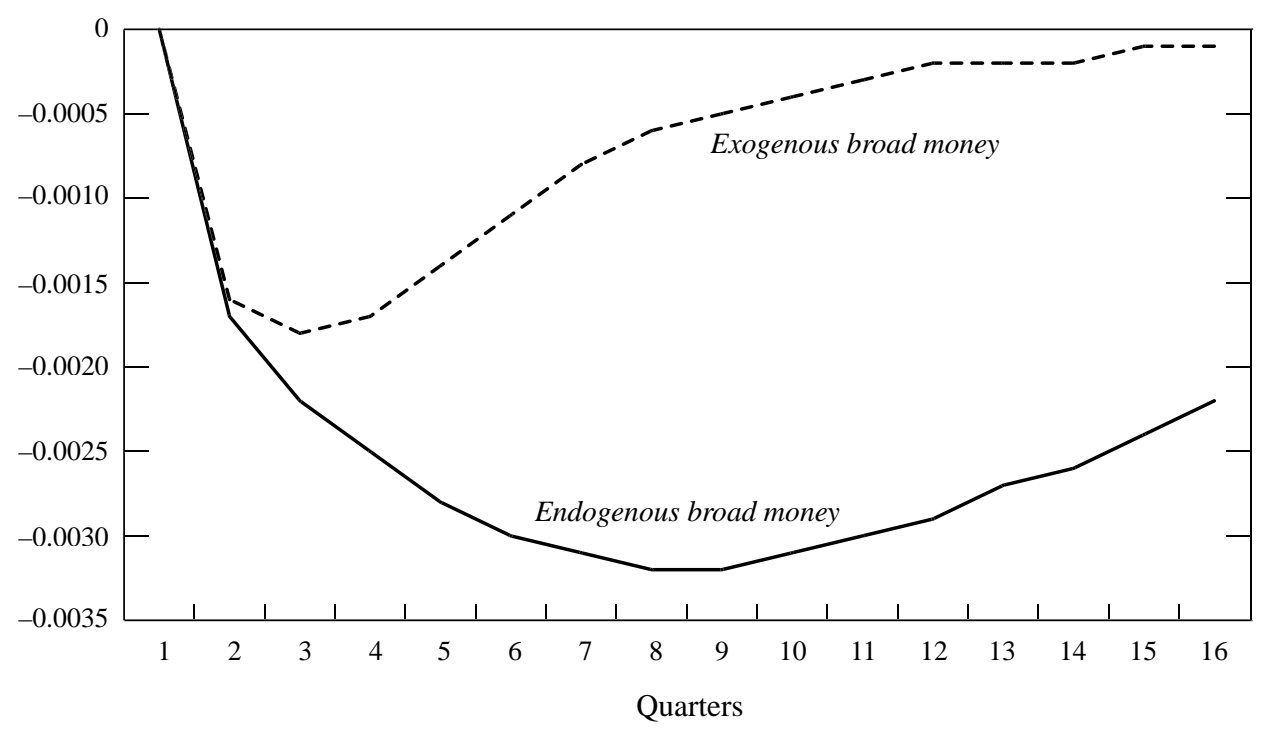

Source: Authors' calculations.

response of aggregate demand to broad money. This suggests that, at least in normal circumstances, quantitative easing may have only limited effects on activity.

\section{Components of Private Demand}

The first experiment we conduct is to examine which components of real private demand are most affected by monetary policy. This is accomplished by rerunning the basic model with real private demand split between the particular component being examined and the remainder of private demand (ordered first to avoid spurious correlations). ${ }^{15}$ For business investment, for example, the VAR involves private demand less business investment, business investment, prices, the overnight call rate, and broad money.

Figure 3 shows the response of the individual demand components to a change in interest rates and a change in broad money. The results indicate that monetary policy operates on the real economy largely through its impact on business investment. A typical innovation in the overnight call rate changes business investment by over 0.2 percentage points of potential output after $2^{1 / 2}$ years, compared to 0.1 percentage points for household spending (the sum of consumption and residential investment) and a negligible effect on net exports. ${ }^{16}$ The importance of business

${ }^{15}$ The components of private demand being consumption, business investment, residential investment, exports, and imports. 
Figure 3. Japan: Components of Private Demand (Response to one S.D. innovations)
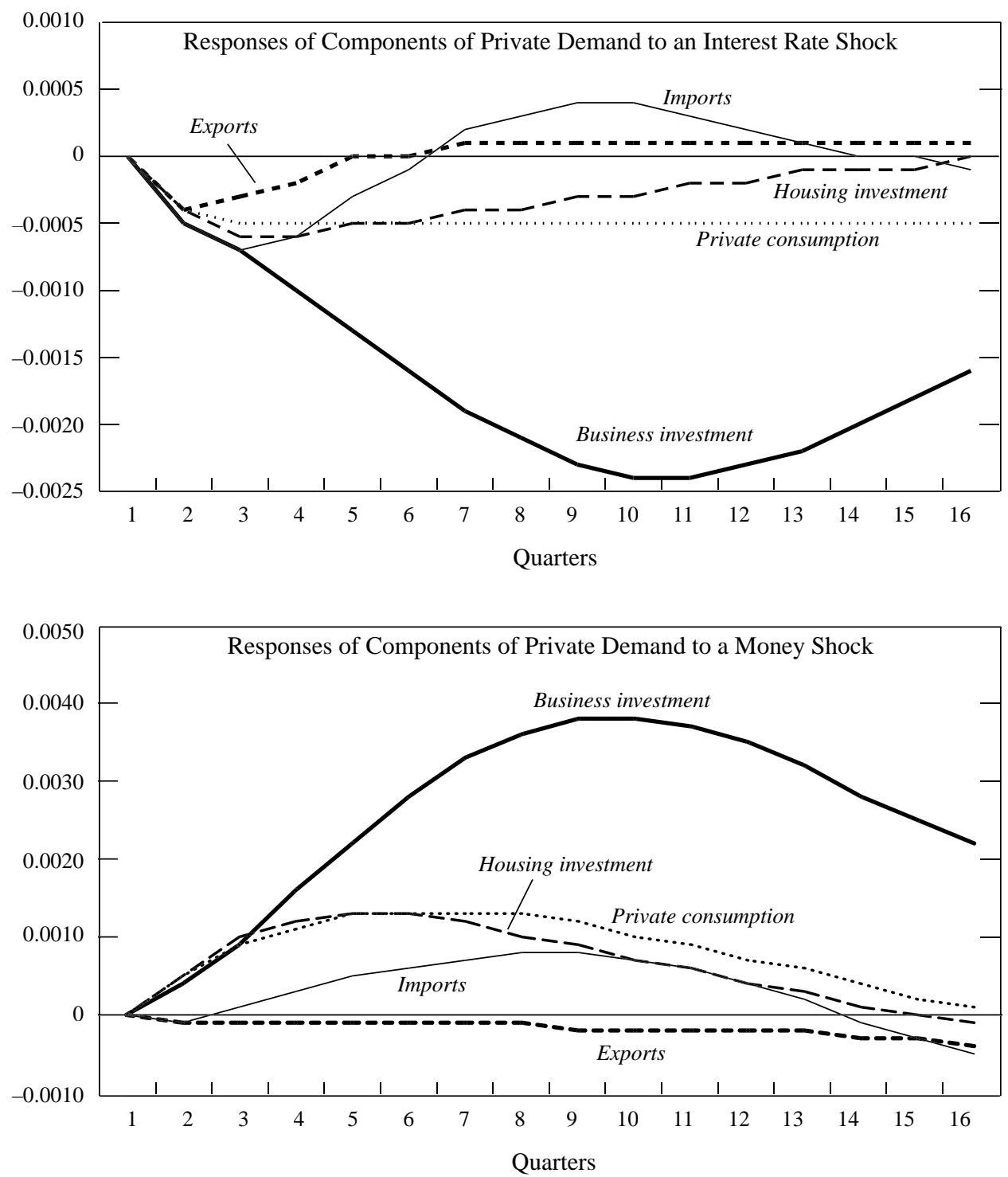

Source: Authors' calculations.

investment is consistent with the view that the bank lending channel dominates the monetary transmission mechanism in Japan, as such investment is largely funded

${ }^{16}$ Note that the sum of these components -0.3 percent of potential-is very close to the result found for total private demand in the basic model, indicating that the decomposition into separate components of demand is broadly consistent with the aggregate results. 
out of bank lending, at least at the margin. Similar results are also found with regard to broad money. Table 2, which reports the variance decompositions for the VAR with business investment, shows that - after two years-monetary factors account for over 50 percent of the fluctuation in business investment.

\section{Private Sector Funding}

The second extension to the basic model involves adding the main components of private sector funding: bank loans to corporations and households (hereafter simply called bank loans), loans from government financial institutions to these same sectors (henceforth, public loans), and funds raised by corporations through securities markets. ${ }^{17}$ So the VAR comprises (in order) private demand, prices, the overnight call rate, broad money, public loans, funds from securities markets, and bank loans. As discussed further below, the following conclusions emerge: (i) bank loans are both an important conduit for the monetary transmission mechanism and a significant source of independent shocks to private demand, while funds from securities markets and public loans have neither of these characteristics; and (ii) innovations to bank loans elicit no significant response from securities markets or public loans (in other words, there is no effective substitute for bank loans), while increases in public loans are almost entirely offset by subsequent reductions in bank loans and securities markets funding. Public loans substitute for private credit, helping to explain why they have little impact on demand.

The addition of these private sector funding variables has almost no impact on the responses within the basic model, with one important exception, namely that the impact of the overnight rate on demand becomes insignificant (see Appendix II). As this is the main transmission channel for monetary policy in the model, this result would be important if it turned out to be robust. Further investigation indicates, however, that this result is reversed when the series measuring funds raised in securities markets is eliminated from the VAR. As this variable has very little impact on the rest of the model, and this is the only case in which our monetary VARs produce an insignificant interest rate response on output, we view this effect as a statistical aberration.

Turning to the results for the three additional variables, the impulse responses indicate that innovations to bank loans unconnected with interest rates and activity have a large and significant impact on private demand, with a ¥100 increase in bank loans leading to a $¥ 50$ increase in real demand (Figure 4). By contrast, independent increases in funds from securities markets or public loans have no significant impact on demand. In the case of securities markets, this appears to reflect their limited importance in financial intermediation (comparing the size of own responses, the typical innovation to credit from securities markets is only twofifths that of bank loans). For public loans, which are a more important component of the financial transmission mechanism, the results show that a rise in public

${ }^{17}$ These data come from the flow of funds accounts. The securities markets series aggregates funds from bonds, corporate paper, and equities. 
Table 2. Japan: Variance Decompositions for the Business Investment Model (In percent)

Variance Decomposition of Private Demand Minus Business Investment

\begin{tabular}{ccccccc} 
Quarter & $\begin{array}{c}\text { Forecast } \\
\text { Error }\end{array}$ & $\begin{array}{c}\text { Other } \\
\text { Activity }\end{array}$ & $\begin{array}{c}\text { Business } \\
\text { Investment }\end{array}$ & $\begin{array}{c}\text { Price } \\
\text { Level }\end{array}$ & $\begin{array}{c}\text { Interest } \\
\text { Rates }\end{array}$ & $\begin{array}{c}\text { Broad } \\
\text { Money }\end{array}$ \\
\hline 4 & 0.5 & 63.1 & 10.9 & 2.0 & 13.8 & 10.3 \\
8 & 0.7 & 40.7 & 7.7 & 6.4 & 17.7 & 27.4 \\
12 & 0.7 & 35.1 & 6.0 & 8.9 & 18.3 & 31.7 \\
16 & 0.8 & 34.0 & 5.7 & 9.2 & 18.5 & 32.6
\end{tabular}

\begin{tabular}{rcccccc}
\multicolumn{7}{c}{ Variance Decomposition of Business Investment } \\
Quarter & $\begin{array}{c}\text { Forecast } \\
\text { Error }\end{array}$ & $\begin{array}{c}\text { Other } \\
\text { Activity }\end{array}$ & $\begin{array}{c}\text { Business } \\
\text { Investment }\end{array}$ & $\begin{array}{c}\text { Price } \\
\text { Level }\end{array}$ & $\begin{array}{c}\text { Interest } \\
\text { Rates }\end{array}$ & $\begin{array}{c}\text { Broad } \\
\text { Money }\end{array}$ \\
4 & 0.6 & 12.1 & 73.9 & 0.3 & 4.4 & 9.3 \\
8 & 1.0 & 6.3 & 35.1 & 7.9 & 12.6 & 38.1 \\
12 & 1.5 & 7.1 & 17.7 & 15.3 & 16.2 & 43.7 \\
16 & 1.7 & 9.3 & 13.5 & 16.9 & 17.3 & 43.0
\end{tabular}

\begin{tabular}{|c|c|c|c|c|c|c|}
\hline \multicolumn{7}{|c|}{ Variance Decomposition of Price Level } \\
\hline Quarter & $\begin{array}{l}\text { Forecast } \\
\text { Error }\end{array}$ & $\begin{array}{c}\text { Other } \\
\text { Activity }\end{array}$ & $\begin{array}{l}\text { Business } \\
\text { Investment }\end{array}$ & $\begin{array}{l}\text { Price } \\
\text { Level }\end{array}$ & $\begin{array}{c}\text { Interest } \\
\text { Rates }\end{array}$ & $\begin{array}{l}\text { Broad } \\
\text { Money }\end{array}$ \\
\hline 4 & 0.7 & 8.1 & 0.8 & 84.2 & 5.9 & 1.0 \\
\hline 8 & 0.9 & 12.4 & 3.5 & 76.3 & 6.6 & 1.2 \\
\hline 12 & 1.0 & 11.8 & 5.8 & 66.7 & 6.4 & 9.3 \\
\hline 16 & 1.1 & 10.0 & 5.5 & 54.5 & 8.9 & 21.1 \\
\hline \multicolumn{7}{|c|}{ Variance Decomposition of Interest Rates } \\
\hline Quarter & $\begin{array}{c}\text { Forecast } \\
\text { Error }\end{array}$ & $\begin{array}{c}\text { Other } \\
\text { Activity }\end{array}$ & $\begin{array}{c}\text { Business } \\
\text { Investment }\end{array}$ & $\begin{array}{l}\text { Price } \\
\text { Level }\end{array}$ & $\begin{array}{c}\text { Interest } \\
\text { Rates }\end{array}$ & $\begin{array}{l}\text { Broad } \\
\text { Money }\end{array}$ \\
\hline 4 & 1.0 & 2.2 & 0.0 & 22.1 & 75.1 & 0.4 \\
\hline 8 & 1.1 & 3.6 & 1.1 & 23.5 & 60.7 & 11.2 \\
\hline 12 & 1.3 & 6.0 & 1.1 & 27.0 & 46.8 & 19.1 \\
\hline 16 & 1.4 & 7.4 & 1.0 & 27.6 & 42.7 & 21.3 \\
\hline \multicolumn{7}{|c|}{ Variance Decomposition of Broad Money } \\
\hline Quarter & $\begin{array}{c}\text { Forecast } \\
\text { Error }\end{array}$ & $\begin{array}{l}\text { Other } \\
\text { Activity }\end{array}$ & $\begin{array}{l}\text { Business } \\
\text { Investment }\end{array}$ & $\begin{array}{l}\text { Price } \\
\text { Level }\end{array}$ & $\begin{array}{c}\text { Interest } \\
\text { Rates }\end{array}$ & $\begin{array}{l}\text { Broad } \\
\text { Money }\end{array}$ \\
\hline 4 & 2.1 & 5.4 & 4.3 & 15.3 & 6.9 & 68.1 \\
\hline 8 & 3.6 & 8.5 & 2.8 & 21.3 & 13.8 & 53.6 \\
\hline 12 & 4.4 & 9.8 & 2.3 & 22.0 & 16.2 & 49.8 \\
\hline 16 & 4.7 & 10.1 & 2.3 & 21.4 & 17.0 & 49.2 \\
\hline
\end{tabular}

Source: Authors' calculations. 
Figure 4. Japan: Response of Private Demand to Funding Shocks

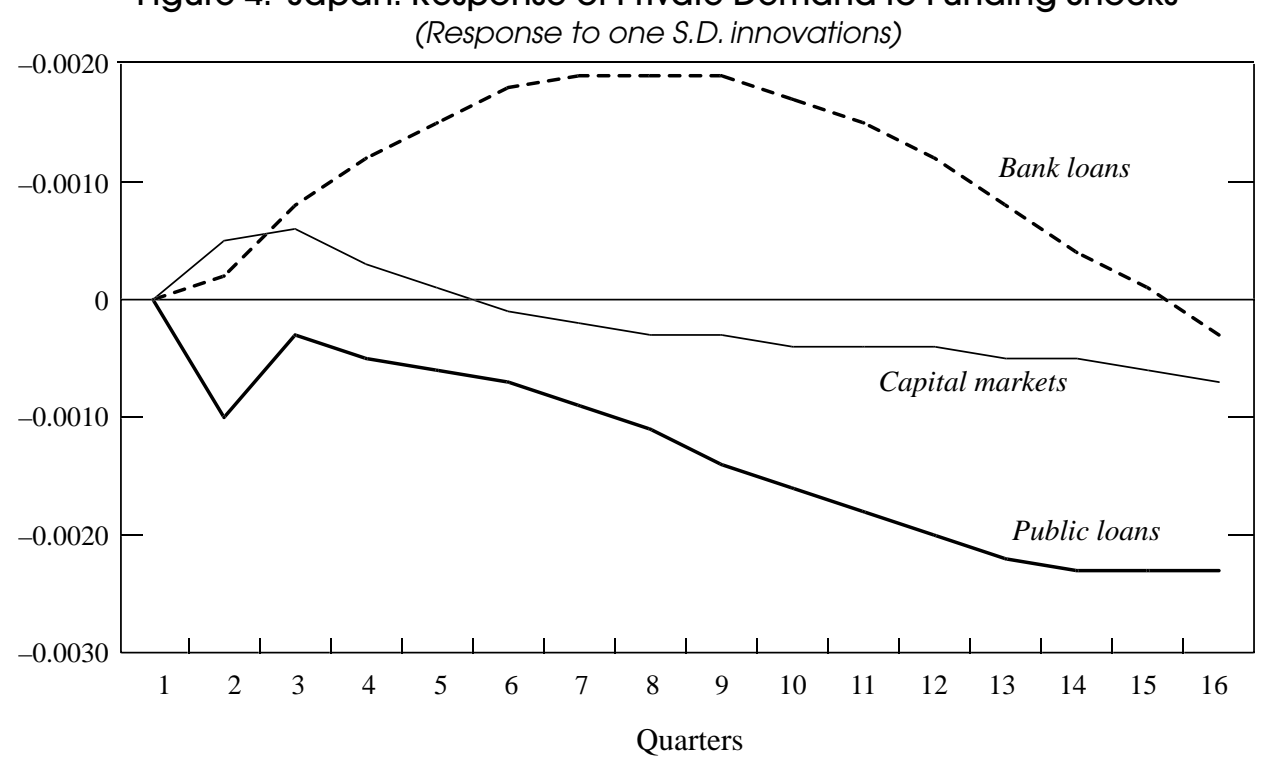

Source: Authors' calculations.

loans is followed by reduction in privately-sourced funds. Furthermore, these results are similar if different orderings of the three additional variables are used.

Figure 5 shows how the three new variables respond to each other, in other words, the degree of substitution between different forms of private sector funding. As can be seen in the bottom panel of the figure, an increase in bank loans elicits no significant response from either securities markets or government financial institutions, implying that shocks to bank credit translate almost one-for-one into lower borrowing by the private sector. By contrast, as can be seen in the top panel, an increase in public loans is offset quite rapidly by reductions in bank loans and credit from securities markets-public loans are generally a substitute for private funds, not an addition to them. This very different set of responses helps to explain why bank loans have a direct impact on demand, but public loans do not. Table 3 presents the variance decompositions, which show that bank loans account for about 10 percent of the fluctuation in private demand after two years.

The role of different sources of funds in the monetary transmission mechanism was explored by rerunning the VAR with each of the funding variables being exogenized in the same manner that broad money was exogenized earlier, so that any responses involving these variables are eliminated. Exogenizing bank loans leads to a dramatic reduction in the impact of broad money on private demand, while exogenizing funds from securities markets and public sector loans produces almost no change in this money effect, indicating that bank loans are the main transmission mechanism of monetary disturbances to the real economy. ${ }^{18}$

\footnotetext{
${ }^{18}$ Responses of short-term interest rates are not reported as they were small and insignificant in the main model, as discussed earlier.
} 
James Morsink and Tamim Bayoumi

Figure 5. Japan: Substitution Between Sources of Funding (Response to one S.D. innovations)
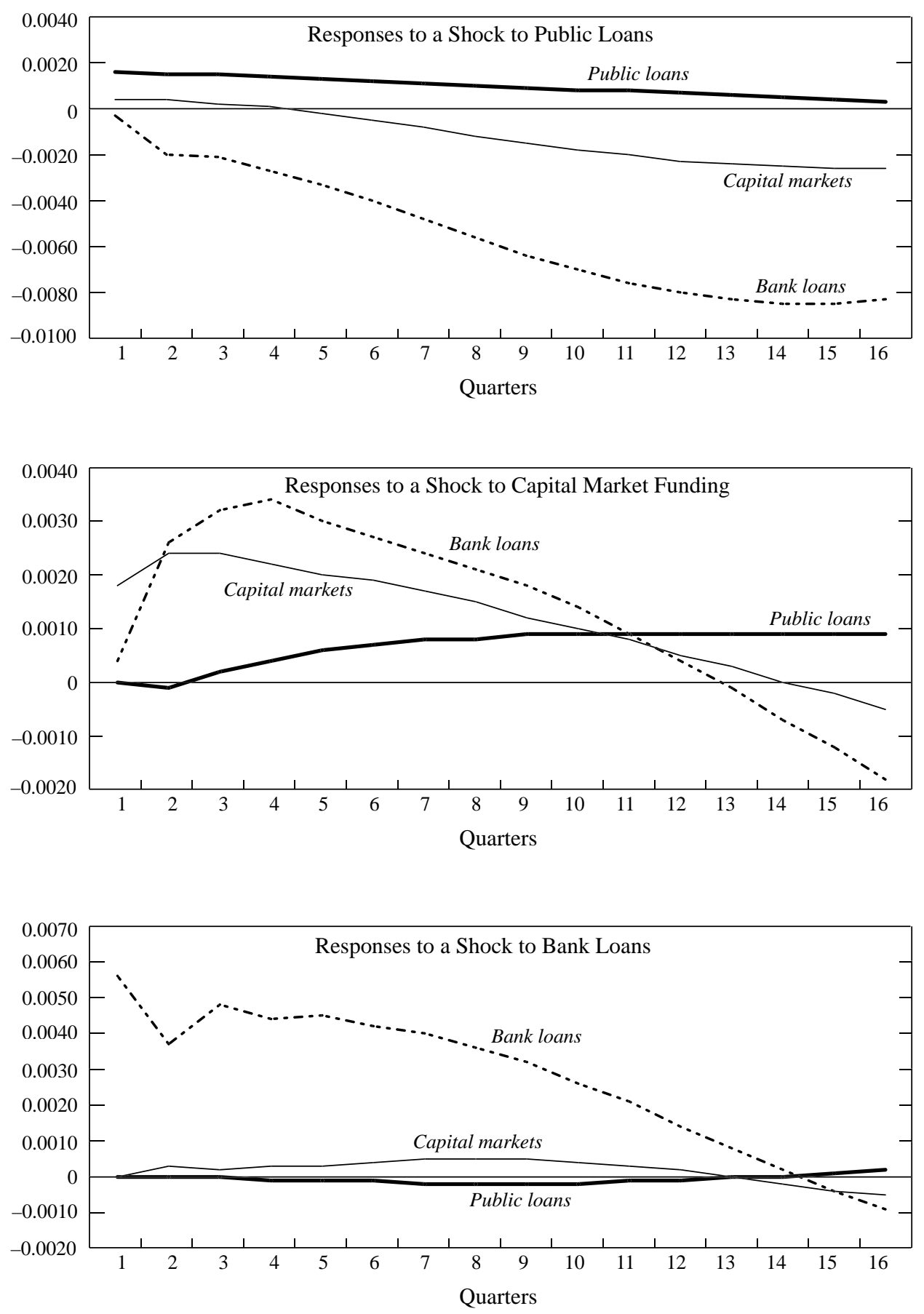

Source: Authors' calculations. 
Table 3. Japan: Variance Decompositions for the Private Sector Funding Model

$$
\text { (In percent) }
$$

\begin{tabular}{cccccccccc}
\multicolumn{8}{c}{ Variance Decomposition of Private Demand } \\
Quarter & $\begin{array}{c}\text { Forecast } \\
\text { Error }\end{array}$ & $\begin{array}{c}\text { Private } \\
\text { Demand }\end{array}$ & $\begin{array}{c}\text { Price } \\
\text { Level }\end{array}$ & $\begin{array}{c}\text { Interest } \\
\text { Rates }\end{array}$ & $\begin{array}{c}\text { Broad } \\
\text { Money }\end{array}$ & $\begin{array}{c}\text { Public } \\
\text { Loans }\end{array}$ & $\begin{array}{c}\text { Capital } \\
\text { Markets }\end{array}$ & $\begin{array}{c}\text { Bank } \\
\text { Loans }\end{array}$ \\
\hline 4 & 0.9 & 71.0 & 1.9 & 1.4 & 20.7 & 1.7 & 0.9 & 2.6 \\
8 & 1.2 & 40.3 & 2.6 & 1.3 & 42.8 & 2.8 & 0.5 & 9.6 \\
12 & 1.5 & 40.5 & 2.8 & 0.9 & 37.9 & 6.9 & 0.6 & 10.4 & 8.6 \\
16 & 1.7 & 42.8 & 2.8 & 1.6 & 30.8 & 12.5 & 0.9 & &
\end{tabular}

\begin{tabular}{cccccccccc}
\multicolumn{8}{c}{ Variance Decomposition of Price Level } \\
Quarter & $\begin{array}{c}\text { Forecast } \\
\text { Error }\end{array}$ & $\begin{array}{c}\text { Private } \\
\text { Demand }\end{array}$ & $\begin{array}{c}\text { Price } \\
\text { Level }\end{array}$ & $\begin{array}{c}\text { Interest } \\
\text { Rates }\end{array}$ & $\begin{array}{c}\text { Broad } \\
\text { Money }\end{array}$ & $\begin{array}{c}\text { Public } \\
\text { Loans }\end{array}$ & $\begin{array}{c}\text { Capital } \\
\text { Markets }\end{array}$ & $\begin{array}{c}\text { Bank } \\
\text { Loans }\end{array}$ \\
4 & 0.5 & 18.2 & 74.4 & 0.6 & 0.1 & 6.1 & 0.3 & 0.3 \\
8 & 0.7 & 30.0 & 50.3 & 2.1 & 3.7 & 9.2 & 4.0 & 0.7 & 5.4 \\
12 & 0.8 & 24.0 & 37.8 & 5.0 & 11.7 & 8.7 & 7.4 & 7.6 & 9.7
\end{tabular}

\begin{tabular}{|c|c|c|c|c|c|c|c|c|}
\hline \multicolumn{9}{|c|}{ Variance Decomposition of Interest Rates } \\
\hline Quarter & $\begin{array}{c}\text { Forecast } \\
\text { Error }\end{array}$ & $\begin{array}{l}\text { Private } \\
\text { Demand }\end{array}$ & $\begin{array}{l}\text { Price } \\
\text { Level }\end{array}$ & $\begin{array}{c}\text { Interest } \\
\text { Rates }\end{array}$ & $\begin{array}{l}\text { Broad } \\
\text { Money }\end{array}$ & $\begin{array}{l}\text { Public } \\
\text { Loans }\end{array}$ & $\begin{array}{l}\text { Capital } \\
\text { Markets }\end{array}$ & $\begin{array}{c}\text { Bank } \\
\text { Loans }\end{array}$ \\
\hline 4 & 0.6 & 17.4 & 8.3 & 60.0 & 10.7 & 0.4 & 2.7 & 0.5 \\
\hline 8 & 0.8 & 12.4 & 6.9 & 40.0 & 24.9 & 0.4 & 13.8 & 1.5 \\
\hline 12 & 0.9 & 16.1 & 10.7 & 31.5 & 24.4 & 1.7 & 14.3 & 1.4 \\
\hline 16 & 1.0 & 20.0 & 11.2 & 26.7 & 21.7 & 6.6 & 12.3 & 1.5 \\
\hline \multicolumn{9}{|c|}{ Variance Decomposition of Broad Money } \\
\hline Quarter & $\begin{array}{c}\text { Forecast } \\
\text { Error }\end{array}$ & $\begin{array}{l}\text { Private } \\
\text { Demand }\end{array}$ & $\begin{array}{l}\text { Price } \\
\text { Level }\end{array}$ & $\begin{array}{c}\text { Interest } \\
\text { Rates }\end{array}$ & $\begin{array}{l}\text { Broad } \\
\text { Money }\end{array}$ & $\begin{array}{l}\text { Public } \\
\text { Loans }\end{array}$ & $\begin{array}{l}\text { Capital } \\
\text { Markets }\end{array}$ & $\begin{array}{c}\text { Bank } \\
\text { Loans }\end{array}$ \\
\hline 4 & 1.5 & 3.5 & 2.1 & 0.3 & 82.4 & 4.6 & 5.8 & 1.3 \\
\hline 8 & 2.2 & 19.9 & 5.0 & 0.4 & 57.5 & 11.7 & 4.6 & 0.9 \\
\hline 12 & 2.7 & 23.8 & 4.0 & 1.1 & 44.1 & 22.1 & 3.7 & 1.2 \\
\hline 16 & 3.0 & 20.2 & 6.5 & 3.2 & 34.5 & 26.0 & 5.5 & 4.2 \\
\hline
\end{tabular}

\begin{tabular}{cccccccccc}
\multicolumn{8}{c}{ Variance Decomposition of Public Loans } \\
Quarter & $\begin{array}{c}\text { Forecast } \\
\text { Error }\end{array}$ & $\begin{array}{c}\text { Private } \\
\text { Demand }\end{array}$ & $\begin{array}{c}\text { Price } \\
\text { Level }\end{array}$ & $\begin{array}{c}\text { Interest } \\
\text { Rates }\end{array}$ & $\begin{array}{c}\text { Broad } \\
\text { Money }\end{array}$ & $\begin{array}{c}\text { Public } \\
\text { Loans }\end{array}$ & $\begin{array}{c}\text { Capital } \\
\text { Markets }\end{array}$ & $\begin{array}{c}\text { Bank } \\
\text { Loans }\end{array}$ \\
4 & 0.3 & 9.3 & 3.3 & 3.6 & 3.9 & 78.2 & 1.6 & 0.0 \\
8 & 0.6 & 22.2 & 8.4 & 4.3 & 14.7 & 42.9 & 7.2 & 0.3 \\
12 & 0.8 & 21.4 & 10.2 & 3.6 & 24.6 & 29.8 & 10.0 & 0.3 \\
16 & 0.8 & 19.9 & 12.3 & 3.5 & 26.2 & 25.1 & 12.7 & 0.3
\end{tabular}


James Morsink and Tamim Bayoumi

\begin{tabular}{|c|c|c|c|c|c|c|c|c|}
\hline \multicolumn{9}{|c|}{ Table 3. (concluded) } \\
\hline \multicolumn{9}{|c|}{ Variance Decomposition of Securities Markets Funding } \\
\hline Quarter & $\begin{array}{l}\text { Forecast } \\
\text { Error }\end{array}$ & $\begin{array}{l}\text { Private } \\
\text { Demand }\end{array}$ & $\begin{array}{l}\text { Price } \\
\text { Level }\end{array}$ & $\begin{array}{c}\text { Interest } \\
\text { Rates }\end{array}$ & $\begin{array}{l}\text { Broad } \\
\text { Money }\end{array}$ & $\begin{array}{l}\text { Public } \\
\text { Loans }\end{array}$ & $\begin{array}{c}\text { Capital } \\
\text { Markets }\end{array}$ & $\begin{array}{c}\text { Bank } \\
\text { Loans }\end{array}$ \\
\hline 4 & 0.6 & 9.7 & 14.0 & 2.1 & 16.8 & 1.0 & 55.9 & 0.5 \\
\hline 8 & 1.0 & 27.7 & 20.3 & 3.2 & 11.1 & 2.8 & 34.0 & 0.9 \\
\hline 12 & 1.2 & 36.8 & 17.9 & 2.1 & 8.7 & 11.0 & 22.8 & 0.8 \\
\hline 16 & 1.4 & 34.5 & 14.4 & 2.6 & 7.9 & 21.6 & 18.0 & 0.9 \\
\hline \multicolumn{9}{|c|}{ Variance Decomposition of Bank Loans } \\
\hline Quarter & $\begin{array}{c}\text { Forecast } \\
\text { Error }\end{array}$ & $\begin{array}{l}\text { Private } \\
\text { Demand }\end{array}$ & $\begin{array}{l}\text { Price } \\
\text { Level }\end{array}$ & $\begin{array}{c}\text { Interest } \\
\text { Rates }\end{array}$ & $\begin{array}{l}\text { Broad } \\
\text { Money }\end{array}$ & $\begin{array}{l}\text { Public } \\
\text { Loans }\end{array}$ & $\begin{array}{c}\text { Capital } \\
\text { Markets }\end{array}$ & $\begin{array}{c}\text { Bank } \\
\text { Loans }\end{array}$ \\
\hline 4 & 1.7 & 9.0 & 3.8 & 0.6 & 42.1 & 5.3 & 9.7 & 29.7 \\
\hline 8 & 2.9 & 29.1 & 4.6 & 0.5 & 29.1 & 11.6 & 6.6 & 18.4 \\
\hline 12 & 3.7 & 34.3 & 3.1 & 0.6 & 22.7 & 22.1 & 4.4 & 12.7 \\
\hline 16 & 4.3 & 28.2 & 4.1 & 1.8 & 20.8 & 31.8 & 3.6 & 9.7 \\
\hline
\end{tabular}

\section{Bank Lending}

This section further examines the role of banks in the monetary transmission mechanism by adding to the basic model the main components of bank assets, namely loans and holdings of securities. Including banks' balance sheets in the analysis yields the following insights into the monetary transmission mechanism in Japan: (i) shocks to bank loans have a positive and significant effect on private demand, even controlling for interest rates and broad money; (ii) the impulse responses of private demand to interest rate and money shocks are reduced when bank loans are exogenized, suggesting that bank loans are an important transmission channel; and (iii) the addition of relative bank stock prices to the VAR suggests that bank loan shocks may largely reflect innovations to bank strength.

The bank lending VAR includes private demand, prices, interest rates, broad money, bank loans, and banks' holdings of securities. The impulse responses for the basic model variables are generally similar to the results reported previously, with the overnight call rate having a significantly negative effect — and broad money a significantly positive effect—on private demand (see Appendix II). The response of private demand to a broad money shock is somewhat smaller than that in the basic model, suggesting that part of the broad money shocks in the basic model reflect bank lending shocks (top panel of Figure 6). Turning to the impact of the additional variables on private demand, a shock to bank lending credit has a positive and long-lasting effect—a $¥ 100$ increase in bank lending increases private demand by almost $¥ 50$ - while shocks to securities have little short-term impact (middle panel of Figure 6). The variance decompositions (Table 4) also 


\section{A PEEK INSIDE THE BLACK BOX}

Figure 6. Japan: Impulse Responses for Bank Lending Model (Response to one S.D. innovations)
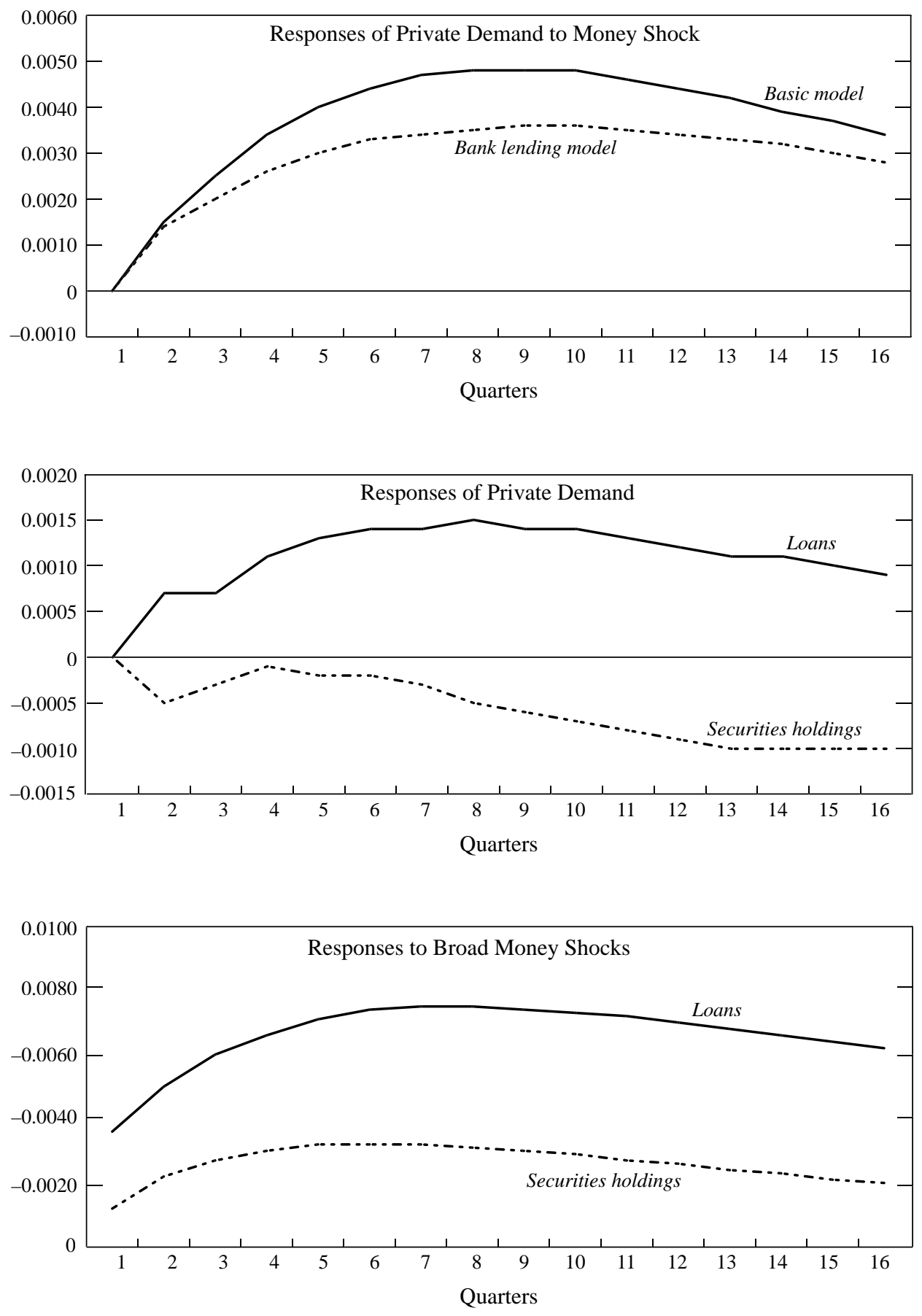

Source: Authors' calculations. 


\begin{tabular}{|c|c|c|c|c|c|c|c|}
\hline \multicolumn{8}{|c|}{$\begin{array}{l}\text { Table 4. Japan: Variance Decompositions } \\
\text { (In percent) }\end{array}$} \\
\hline \multicolumn{8}{|c|}{ Variance Decomposition of Private Demand } \\
\hline Quarter & $\begin{array}{c}\text { Forecast } \\
\text { Error }\end{array}$ & $\begin{array}{l}\text { Private } \\
\text { Demand }\end{array}$ & $\begin{array}{l}\text { Price } \\
\text { Level }\end{array}$ & $\begin{array}{c}\text { Interest } \\
\text { Rates }\end{array}$ & $\begin{array}{l}\text { Broad } \\
\text { Money }\end{array}$ & $\begin{array}{l}\text { Bank } \\
\text { Loans }\end{array}$ & $\begin{array}{c}\text { Securities } \\
\text { Holdings }\end{array}$ \\
\hline 4 & 1.0 & 71.2 & 2.6 & 11.9 & 11.8 & 2.2 & 0.3 \\
\hline 8 & 1.5 & 37.8 & 13.5 & 18.3 & 25.5 & 4.6 & 0.3 \\
\hline 12 & 1.8 & 25.3 & 18.0 & 18.8 & 31.8 & 5.1 & 0.9 \\
\hline 16 & 2.0 & 20.9 & 18.4 & 19.1 & 34.9 & 5.1 & 1.7 \\
\hline \multicolumn{8}{|c|}{ Variance Decomposition of Price Level } \\
\hline Quarter & $\begin{array}{l}\text { Forecast } \\
\text { Error }\end{array}$ & $\begin{array}{l}\text { Private } \\
\text { Demand }\end{array}$ & $\begin{array}{l}\text { Price } \\
\text { Level }\end{array}$ & $\begin{array}{c}\text { Interest } \\
\text { Rates }\end{array}$ & $\begin{array}{l}\text { Broad } \\
\text { Money }\end{array}$ & $\begin{array}{l}\text { Bank } \\
\text { Loans }\end{array}$ & $\begin{array}{c}\text { Securities } \\
\text { Holdings }\end{array}$ \\
\hline 4 & 0.7 & 8.2 & 76.1 & 2.9 & 4.0 & 2.6 & 6.2 \\
\hline 8 & 0.9 & 20.2 & 59.4 & 1.7 & 5.1 & 1.6 & 11.9 \\
\hline 12 & 1.0 & 25.4 & 51.4 & 2.0 & 4.7 & 3.1 & 13.5 \\
\hline 16 & 1.1 & 24.8 & 47.4 & 3.5 & 5.4 & 6.6 & 12.4 \\
\hline \multicolumn{8}{|c|}{ Variance Decomposition of Interest Rates } \\
\hline Quarter & $\begin{array}{c}\text { Forecast } \\
\text { Error }\end{array}$ & $\begin{array}{l}\text { Private } \\
\text { Demand }\end{array}$ & $\begin{array}{l}\text { Price } \\
\text { Level }\end{array}$ & $\begin{array}{c}\text { Interest } \\
\text { Rates }\end{array}$ & $\begin{array}{l}\text { Broad } \\
\text { Money }\end{array}$ & $\begin{array}{l}\text { Bank } \\
\text { Loans }\end{array}$ & $\begin{array}{c}\text { Securities } \\
\text { Holdings }\end{array}$ \\
\hline 4 & 0.9 & 2.9 & 16.2 & 67.4 & 0.6 & 2.3 & 10.6 \\
\hline 8 & 1.1 & 3.3 & 18.6 & 53.2 & 9.4 & 2.4 & 13.1 \\
\hline 12 & 1.3 & 3.4 & 24.9 & 43.4 & 15.2 & 3.4 & 9.8 \\
\hline 16 & 1.4 & 4.4 & 25.6 & 39.1 & 18.0 & 3.6 & 9.3 \\
\hline
\end{tabular}

show that the addition of bank loans to the VAR reduces the fluctuation in private demand that is accounted for by broad money shocks.

Bank loans and securities both respond negatively to an interest rate shock and positively to a money shock (bottom panel of Figure 6). ${ }^{19}$ The fact that the immediate reactions of bank loans and securities are so large, accounting for more than four-fifths of the shock to broad money, shows that a shock to the main component of bank funding (broad money) cannot be immediately offset with a change in other liabilities. In turn, this suggests that banks do not face a perfectly elastic supply of funds and thus need to make an immediate adjustment in assets. Our results show that bank loans and securities respond in similar ways to monetary shocks, which is not consistent with the idea that banks use their relatively liquid

\footnotetext{
${ }^{19}$ When the VAR is run without broad money, the impulse responses of private demand to innovations in bank loans and securities are somewhat larger, consistent with the view that these variables to some extent capture money shocks.
} 


\section{A PEEK INSIDE THE BLACK BOX}

Table 4. (concluded)

Variance Decomposition of Broad Money

$\begin{array}{cccccccc}\text { Quarter } & \begin{array}{c}\text { Forecast } \\ \text { Error }\end{array} & \begin{array}{c}\text { Private } \\ \text { Demand }\end{array} & \begin{array}{c}\text { Price } \\ \text { Level }\end{array} & \begin{array}{c}\text { Interest } \\ \text { Rates }\end{array} & \begin{array}{c}\text { Broad } \\ \text { Money }\end{array} & \begin{array}{c}\text { Bank } \\ \text { Loans }\end{array} & \begin{array}{c}\text { Securities } \\ \text { Holdings }\end{array} \\ 4 & 2.1 & 0.5 & 20.0 & 9.5 & 67.4 & 1.3 & 1.4 \\ 8 & 3.5 & 1.7 & 25.6 & 14.5 & 55.5 & 2.2 & 0.6 \\ 12 & 4.2 & 3.0 & 25.6 & 15.4 & 52.6 & 2.4 & 1.1 \\ 16 & 4.5 & 3.4 & 24.4 & 15.8 & 52.5 & 2.3 & 1.6\end{array}$

Variance Decomposition of Bank Loans

\begin{tabular}{cccccccc} 
Quarter & $\begin{array}{c}\text { Forecast } \\
\text { Error }\end{array}$ & $\begin{array}{c}\text { Private } \\
\text { Demand }\end{array}$ & $\begin{array}{c}\text { Price } \\
\text { Level }\end{array}$ & $\begin{array}{c}\text { Interest } \\
\text { Rates }\end{array}$ & $\begin{array}{c}\text { Broad } \\
\text { Money }\end{array}$ & $\begin{array}{c}\text { Bank } \\
\text { Loans }\end{array}$ & $\begin{array}{c}\text { Securities } \\
\text { Holdings }\end{array}$ \\
\hline 4 & 1.6 & 0.8 & 23.2 & 11.2 & 45.6 & 18.5 & 0.8 \\
8 & 2.8 & 0.3 & 22.2 & 17.7 & 41.6 & 14.4 & 3.8 \\
12 & 3.6 & 0.2 & 18.9 & 19.8 & 41.4 & 13.3 & 6.4 \\
16 & 4.1 & 0.3 & 16.0 & 21.4 & 42.0 & 12.7 & 7.5 \\
\hline
\end{tabular}

Variance Decomposition of Securities Holdings

$\begin{array}{cccccccc}\text { Quarter } & \begin{array}{c}\text { Forecast } \\ \text { Error }\end{array} & \begin{array}{c}\text { Private } \\ \text { Demand }\end{array} & \begin{array}{c}\text { Price } \\ \text { Level }\end{array} & \begin{array}{c}\text { Interest } \\ \text { Rates }\end{array} & \begin{array}{c}\text { Broad } \\ \text { Money }\end{array} & \begin{array}{c}\text { Bank } \\ \text { Loans }\end{array} & \begin{array}{c}\text { Securities } \\ \text { Holdings }\end{array} \\ 4 & 0.8 & 1.0 & 24.4 & 5.3 & 40.2 & 5.3 & 23.8 \\ 8 & 1.2 & 2.9 & 30.4 & 10.1 & 40.8 & 5.8 & 10.0 \\ 12 & 1.5 & 4.0 & 29.8 & 12.0 & 40.4 & 6.2 & 7.6 \\ 16 & 1.7 & 4.0 & 27.5 & 13.2 & 41.0 & 6.3 & 8.1\end{array}$

Source: Authors' calculations.

assets (securities) as a temporary shock absorber and adjust their loans over the longer run, as they do in the United States. ${ }^{20}$

The role of bank loans in the transmission mechanism can be further examined by exogenizing bank loans in the calculation of the impulse responses. Exogenizing bank loans sharply dampens the impulse response of private demand to both interest rate and broad money shocks (Figure 7). Our results suggest that, after two years, about two-thirds of the direct impact of a change in the overnight call rate on private demand comes through bank loans. By contrast, exogenizing securities holdings does not have these effects. These results indicate that bank loans play an important role in transmitting interest rate and money shocks to economic activity.

Given the importance of bank loans in determining activity, it is useful to try to identify the nature of loan shocks, as distinct from interest rate and money shocks. Motivated by the idea that bank weaknesses could be pushing banks to

${ }^{20}$ See Bernanke and Blinder (1992). 
Figure 7. Japan: Role of Bank Loans in Transmitting Monetary Shocks (Response to one S.D. innovations)
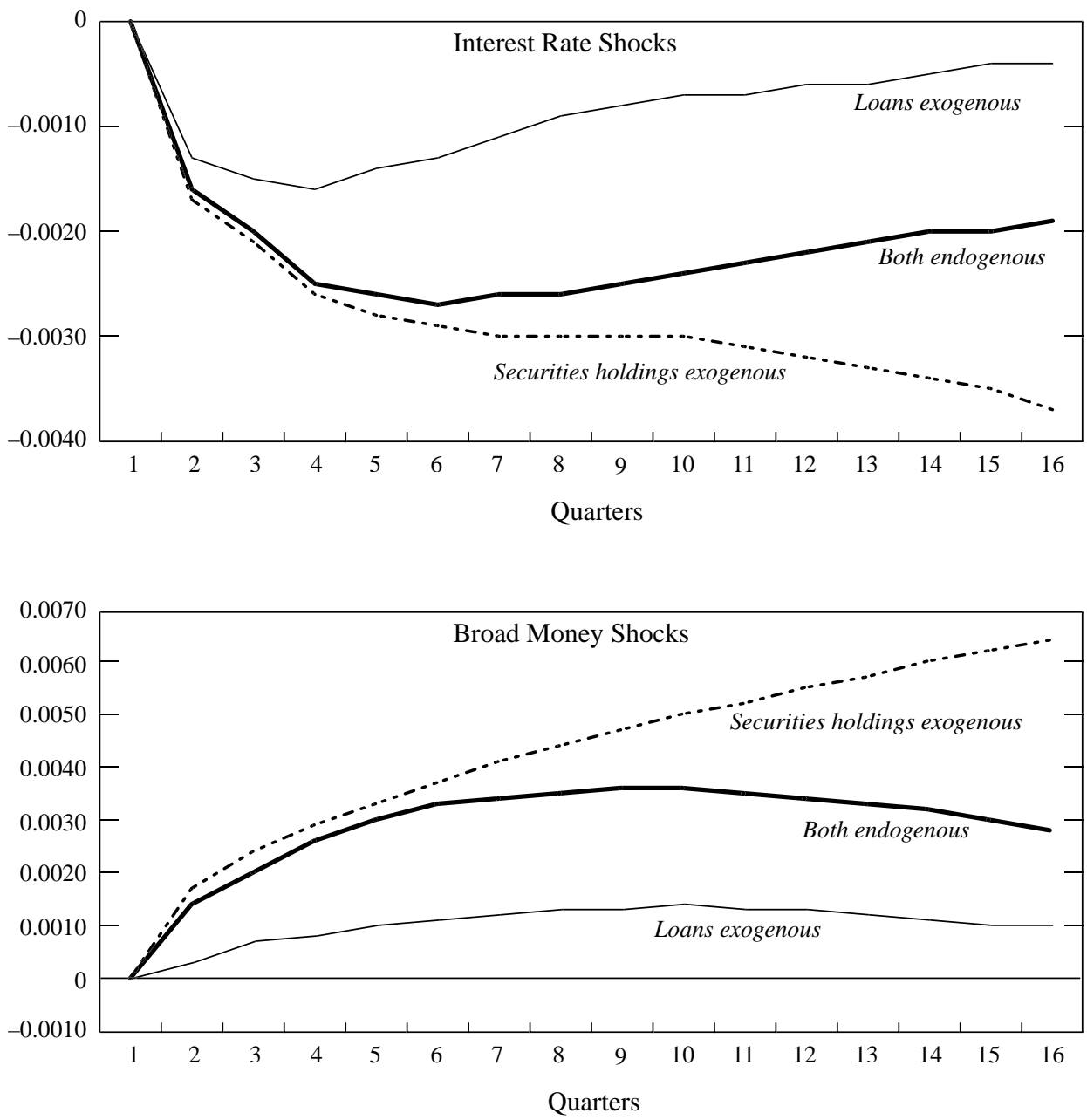

Source: Authors' calculations.

contract lending (a credit crunch), we considered a market-based measure of bank strength, namely the relative value of bank stocks to the overall TOPIX. ${ }^{21}$ When added to the VAR, this variable does a good job of anticipating movements in bank loans, and otherwise generates the anticipated pattern of responses. The impulse response of private demand to bank strength is positive and significant. While private demand still responds positively and significantly to a shock to bank loans,

\footnotetext{
${ }^{21}$ Balance-sheet-based measures of bank strength, such as a bank's reported capital adequacy ratio, are suspect. For example, Long-Term Credit Bank reported a capital adequacy of over 10 percent for March 1998, just a few months before it was found to have negative net worth equivalent to over 14 percent of risk assets.
} 
the size of the response is now smaller. The responses of private demand to interest rate and money shocks are smaller, indicating that part of the impact of such shocks is captured by the measure of bank strength. While it is possible that banks are particularly sensitive to private sector shocks, so a decline in their relative value just reflects real developments, this sensitivity is already taken into account by ordering bank strength last in the VAR, that is, shocks to bank strength are orthogonal to private demand, prices, and money.

An interesting application of these results is to assess the likely impact of the recent decision to inject public funds into major banks on private credit and real demand. In the wake of the enactment of bank legislation in October 1998, which established the framework for the capital injections that eventually occurred in March 1999, bank stock prices recovered strongly - the bank strength variable rose by about 5 percentage points between the third and fourth quarters of 1998 . In terms of the history of this variable, such an improvement is equivalent to a typical (one standard deviation) shock to bank strength. If we attribute this improvement exclusively to a previously unanticipated change in expectations about public capital injections, the estimated results suggest that bank loans will be about 0.5 percent of GDP higher than otherwise after about one year (and private demand about 0.35 percent of GDP higher).

\section{Summary Model}

We now run a single VAR that summarizes our key findings about the role of banks in the monetary transmission mechanism, namely that banks are both a significant source of independent shocks to private demand and an important conduit for interest rate and broad money shocks. The summary VAR differs from the basic model in two crucial aspects. First, reflecting the particular sensitivity of business investment to monetary shocks, the summary VAR splits private demand into business investment and the remainder of private demand. Second, the summary VAR adds bank loans (ordered last).

The impulse responses of this model show that shocks to interest rates, broad money, and bank loans all have large and significant effects on business investment and the remainder of private demand (Figure 8 and Appendix II). The reactions to these shocks of business investment and the remainder of private demand differ in two important ways: (i) the reactions of business investment are two to three times larger, confirming that this component of private demand is particularly sensitive to monetary shocks; and (ii) the reaction to any given shock of business investment builds up more slowly than the reaction of the remainder of private demand, reaching their peaks about one to two years later, which is consistent with the idea that planning processes for business investment are longer than for other components of private demand. The variance decompositions (Table 5) confirm that, after two years, the fraction of the fluctuation in business investment accounted for by monetary factors is larger than that for the remainder of private demand.

The fact that shocks to bank loans have positive and significant effects on private demand, even controlling for interest rates and broad money, confirms that 
Figure 8. Japan: Impulse Responses for Summary Model

(Response to one S.D. innovations)
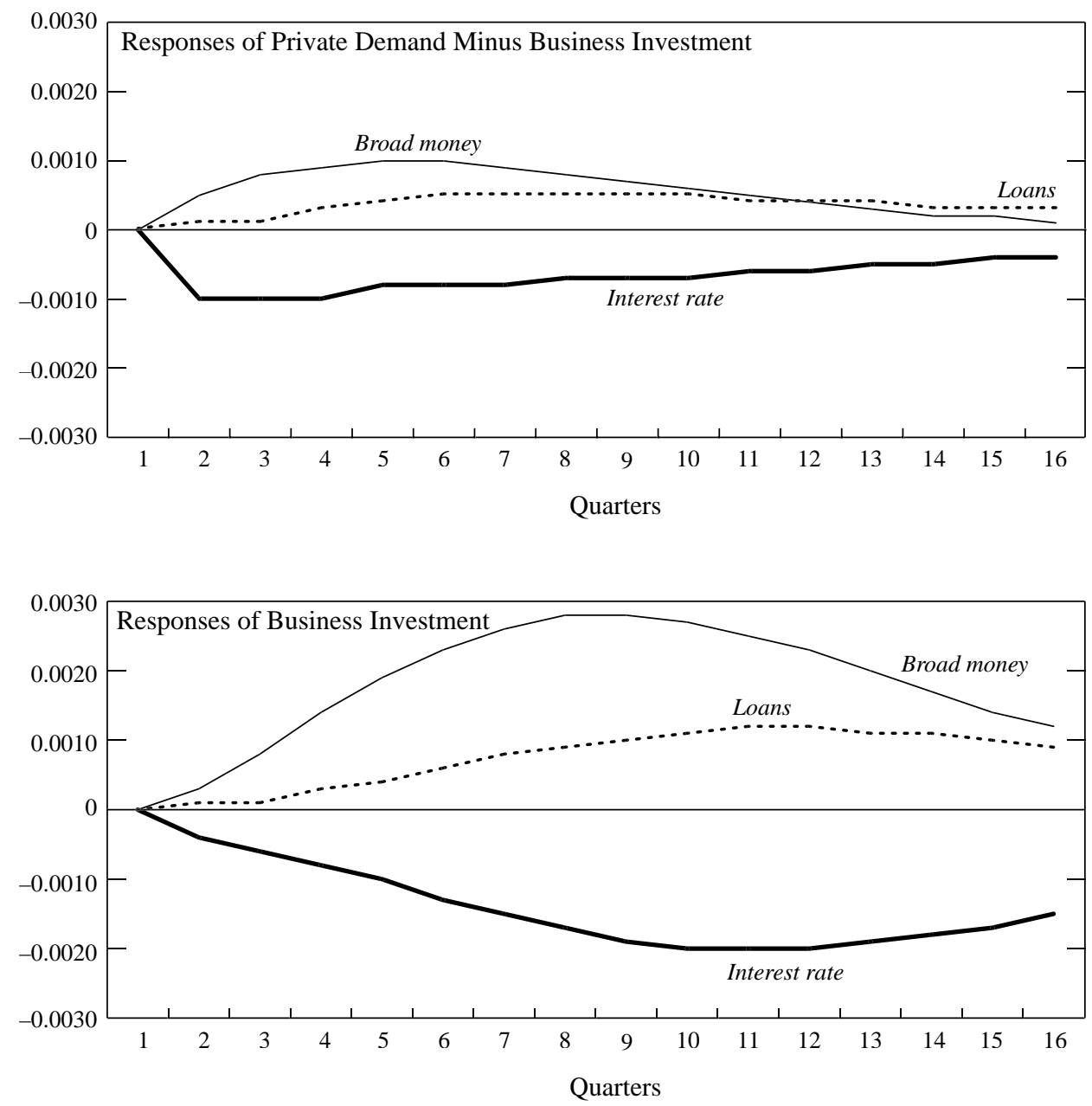

Source: Authors' calculations.

banks play an important independent role in the monetary transmission mechanism. This role of banks as lenders is distinct from that played by the monetary authorities (who determine the overnight call rate) and economic agents more broadly (who decide their demand for money). The fact that the impulse responses of private demand to interest rate and money shocks are reduced when bank loans are exogenized confirms that such shocks are transmitted-at least in partthrough bank loans, suggesting an important role for a bank lending channel.

Finally, we use the results of the summary VAR to decompose the actual path of business investment from 1980 to 1998 into the part predicted by the exogenous 


\begin{tabular}{|c|c|c|c|c|c|c|c|}
\hline \multicolumn{8}{|c|}{$\begin{array}{l}\text { Table 5. Japan: Variance Decompositior } \\
\text { (In percent) }\end{array}$} \\
\hline \multicolumn{8}{|c|}{ Variance Decomposition of Private Demand Minus Business Investment } \\
\hline Quarter & $\begin{array}{l}\text { Forecast } \\
\text { Error }\end{array}$ & $\begin{array}{c}\text { Other } \\
\text { Activity }\end{array}$ & $\begin{array}{l}\text { Business } \\
\text { Investment }\end{array}$ & $\begin{array}{l}\text { Price } \\
\text { Level }\end{array}$ & $\begin{array}{c}\text { Interest } \\
\text { Rates }\end{array}$ & $\begin{array}{l}\text { Broad } \\
\text { Money }\end{array}$ & $\begin{array}{c}\text { Bank } \\
\text { Loans }\end{array}$ \\
\hline 4 & 0.5 & 65.0 & 13.6 & 2.2 & 12.0 & 6.7 & 0.5 \\
\hline 8 & 0.6 & 47.5 & 11.0 & 8.7 & 15.5 & 14.6 & 2.7 \\
\hline 12 & 0.6 & 42.1 & 9.3 & 11.7 & 17.3 & 15.4 & 4.3 \\
\hline 16 & 0.7 & 40.5 & 9.5 & 11.6 & 18.3 & 15.0 & 5.1 \\
\hline \multicolumn{8}{|c|}{ Variance Decomposition of Business Investment } \\
\hline Quarter & $\begin{array}{c}\text { Forecast } \\
\text { Error }\end{array}$ & $\begin{array}{c}\text { Other } \\
\text { Activity }\end{array}$ & $\begin{array}{l}\text { Business } \\
\text { Investment }\end{array}$ & $\begin{array}{l}\text { Price } \\
\text { Level }\end{array}$ & $\begin{array}{c}\text { Interest } \\
\text { Rates }\end{array}$ & $\begin{array}{l}\text { Broad } \\
\text { Money }\end{array}$ & $\begin{array}{c}\text { Bank } \\
\text { Loans }\end{array}$ \\
\hline 4 & 0.6 & 10.2 & 78.1 & 0.4 & 3.5 & 7.6 & 0.2 \\
\hline 8 & 1.0 & 5.9 & 42.9 & 10.5 & 10.0 & 28.6 & 2.2 \\
\hline 12 & 1.3 & 7.6 & 23.4 & 20.4 & 14.2 & 30.3 & 4.0 \\
\hline 16 & 1.5 & 9.2 & 18.6 & 22.4 & 16.5 & 28.3 & 5.0 \\
\hline \multicolumn{8}{|c|}{ Variance Decomposition of Price Level } \\
\hline Quarter & $\begin{array}{c}\text { Forecast } \\
\text { Error }\end{array}$ & $\begin{array}{c}\text { Other } \\
\text { Activity }\end{array}$ & $\begin{array}{l}\text { Business } \\
\text { Investment }\end{array}$ & $\begin{array}{l}\text { Price } \\
\text { Level }\end{array}$ & $\begin{array}{c}\text { Interest } \\
\text { Rates }\end{array}$ & $\begin{array}{l}\text { Broad } \\
\text { Money }\end{array}$ & $\begin{array}{c}\text { Bank } \\
\text { Loans }\end{array}$ \\
\hline 4 & 0.7 & 7.7 & 0.7 & 82.7 & 4.6 & 0.9 & 3.5 \\
\hline 8 & 0.9 & 12.5 & 3.0 & 74.8 & 5.9 & 0.8 & 3.1 \\
\hline 12 & 1.0 & 13.1 & 5.3 & 69.8 & 5.7 & 3.1 & 3.0 \\
\hline 16 & 1.0 & 11.7 & 6.1 & 63.0 & 7.5 & 7.7 & 4.1 \\
\hline
\end{tabular}

variables (constants, time trends, and dummies) and the remainder (the shock). This total shock is then divided into the part explained by innovations in financial variables (overnight call rate, broad money, and bank loans) and that explained by innovations in "real" variables (remainder of private investment, business investment, and prices). The historical decomposition in Figure 9 shows quite nicely how the bubble in the late 1980s was driven by both real factors (including animal spirits) and financial shocks, while the recession of the early 1990s reflected the reversal of both these sets of shocks. Conversely, the pickup in business investment in 1996-97, which helped Japan achieve the most rapid growth rate among OECD countries in 1996, was driven exclusively by real factors, with financial shocks remaining in negative territory. Similarly, the recent abrupt decline in business investment reflects a reversal of these real factors, possibly owing to adverse effects of the Asia crisis on confidence. ${ }^{22}$

\footnotetext{
${ }^{22}$ The results of the decomposition are similar if the VAR is reordered with the financial variables preceding the real variables.
} 
James Morsink and Tamim Bayoumi

\begin{tabular}{|c|c|c|c|c|c|c|c|}
\hline \multicolumn{8}{|c|}{ Table 5. (concluded) } \\
\hline \multicolumn{8}{|c|}{ Variance Decomposition of Interest Rates } \\
\hline Quarter & $\begin{array}{l}\text { Forecast } \\
\text { Error }\end{array}$ & $\begin{array}{c}\text { Other } \\
\text { Activity }\end{array}$ & $\begin{array}{l}\text { Business } \\
\text { Investment }\end{array}$ & $\begin{array}{l}\text { Price } \\
\text { Level }\end{array}$ & $\begin{array}{c}\text { Interest } \\
\text { Rates }\end{array}$ & $\begin{array}{l}\text { Broad } \\
\text { Money }\end{array}$ & $\begin{array}{c}\text { Bank } \\
\text { Loans }\end{array}$ \\
\hline 4 & 1.0 & 2.8 & 0.1 & 23.3 & 71.4 & 0.9 & 1.6 \\
\hline 8 & 1.1 & 4.2 & 1.1 & 24.0 & 56.6 & 12.5 & 1.6 \\
\hline 12 & 1.3 & 7.6 & 1.2 & 28.7 & 42.4 & 18.1 & 2.1 \\
\hline 16 & 1.5 & 9.4 & 1.1 & 29.9 & 39.4 & 19.0 & 2.3 \\
\hline \multicolumn{8}{|c|}{ Variance Decomposition of Broad Money } \\
\hline Quarter & $\begin{array}{l}\text { Forecast } \\
\text { Error }\end{array}$ & $\begin{array}{c}\text { Other } \\
\text { Activity }\end{array}$ & $\begin{array}{l}\text { Business } \\
\text { Investment }\end{array}$ & $\begin{array}{l}\text { Price } \\
\text { Level }\end{array}$ & $\begin{array}{c}\text { Interest } \\
\text { Rates }\end{array}$ & $\begin{array}{l}\text { Broad } \\
\text { Money }\end{array}$ & $\begin{array}{c}\text { Bank } \\
\text { Loans }\end{array}$ \\
\hline 4 & 2.0 & 7.4 & 5.1 & 16.8 & 5.0 & 64.3 & 1.5 \\
\hline 8 & 3.5 & 11.2 & 3.5 & 25.2 & 11.1 & 46.3 & 2.8 \\
\hline 12 & 4.2 & 12.3 & 3.0 & 26.6 & 13.9 & 40.8 & 3.4 \\
\hline 16 & 4.4 & 12.3 & 3.2 & 26.2 & 15.3 & 39.4 & 3.6 \\
\hline \multicolumn{8}{|c|}{ Variance Decomposition of Bank Loans } \\
\hline Quarter & $\begin{array}{c}\text { Forecast } \\
\text { Error }\end{array}$ & $\begin{array}{c}\text { Other } \\
\text { Activity }\end{array}$ & $\begin{array}{l}\text { Business } \\
\text { Investment }\end{array}$ & $\begin{array}{l}\text { Price } \\
\text { Level }\end{array}$ & $\begin{array}{c}\text { Interest } \\
\text { Rates }\end{array}$ & $\begin{array}{l}\text { Broad } \\
\text { Money }\end{array}$ & $\begin{array}{c}\text { Bank } \\
\text { Loans }\end{array}$ \\
\hline 4 & 1.6 & 3.8 & 9.7 & 26.7 & 9.9 & 30.3 & 19.6 \\
\hline 8 & 2.9 & 4.2 & 8.8 & 27.1 & 19.9 & 23.8 & 16.2 \\
\hline 12 & 3.6 & 3.6 & 9.5 & 24.5 & 24.3 & 21.5 & 16.7 \\
\hline 16 & 4.0 & 2.9 & 11.0 & 21.5 & 26.6 & 20.1 & 17.8 \\
\hline
\end{tabular}

Figure 9 also shows the individual components of the financial shocks to business investment: the interest rate shock, the broad money shock, and the bank loans shock. It is interesting that, at least according to our decomposition, interest rate policy was not surprisingly expansionary during the late 1980s-rather, the bubble was driven by money and loan shocks (possibly reflecting irrational exuberance). The sharp swings in money demand in the early 1990s are difficult to explain, but could reflect in part the public's initial rush into bank deposits (accompanying the collapse of asset prices) followed by the realization that banks themselves were in difficulties. Although monetary policy has recently provided some support to private demand, the public's confidence in bank deposits (money demand) and banks' willingness to lend (bank loans) remain weak, underlying the urgency of further progress on bank restructuring. 
Figure 9. Japan: Historical Decomposition of Shocks to Business Investment
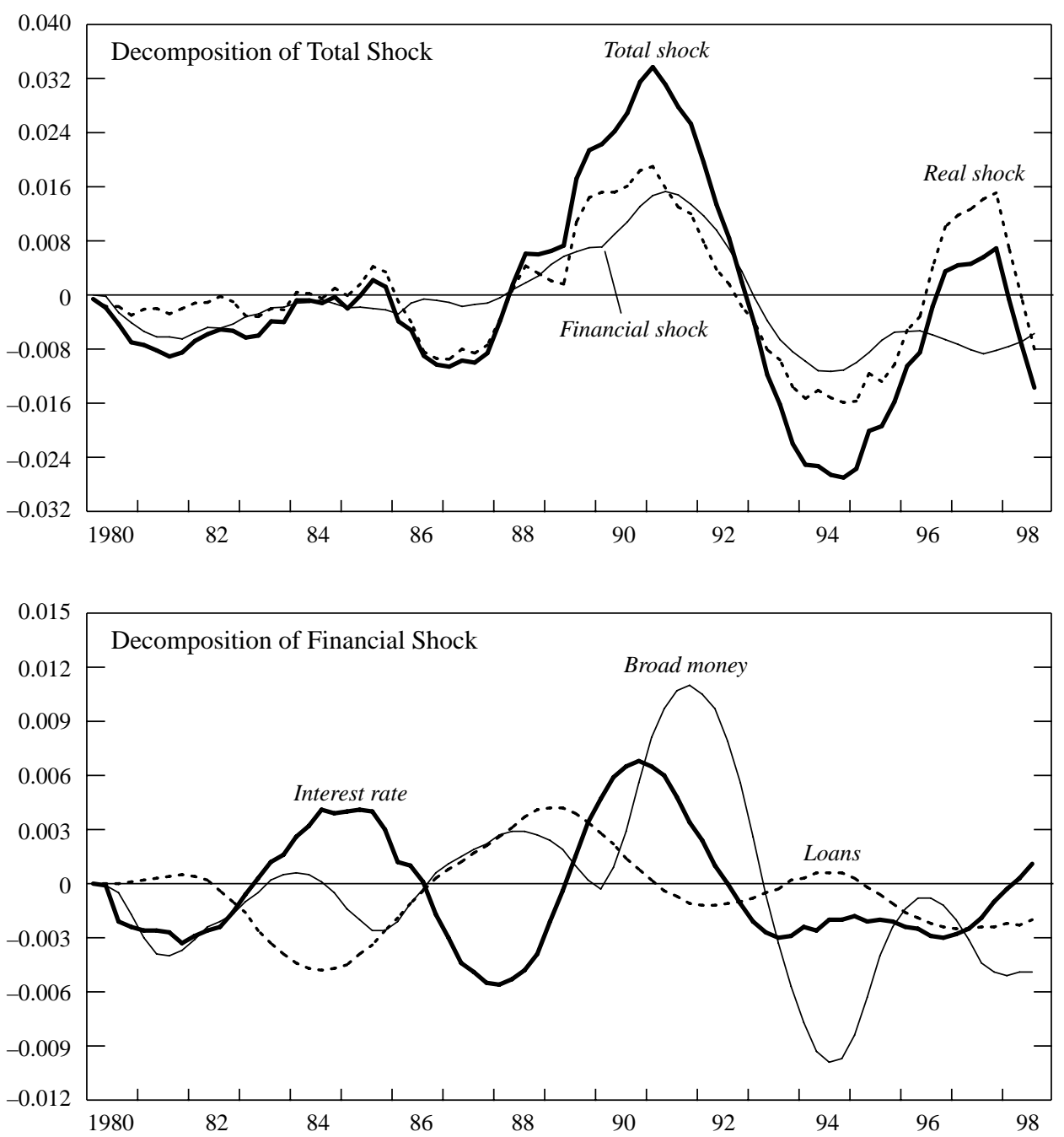

Source: Authors' calculations.

\section{Conclusions}

This paper has used a series of VARs to examine the transmission of monetary shocks to real activity - the so-called black box-in Japan. Starting from a relatively simple specification which describes the overall mechanism, the role of the components of private demand, private sector funding, and bank lending were examined in turn by including relevant additional variables. Finally, a summary VAR was estimated which captures our main findings. The results of these exercises point to a transmission mechanism dominated by banks, in which bank 
lending is both an important independent source of shocks and an important conduit for the transmission of interest rate and broad money shocks to real activity. According to our results, after two years about two-thirds of the direct impact of a change in the overnight call rate on private demand comes through bank loans, and that of this change in private demand about two-thirds comes through business investment. In a further experiment, we found that changes in the monetary base had relatively limited effects on real private demand, suggesting that in normal circumstances quantitative easing may provide limited benefits to activity.

The importance of bank loans in financial intermediation appears to reflect the lack of alternative sources of borrowing for much of the nonfinancial private sector, with neither securities markets nor loans from government financial institutions providing a significant offset to changes in bank loans. In addition, independent disturbances to bank credit also appear to have a significant impact on private demand, and much of this effect can be captured by a measure of bank strength based on equity prices. By contrast, the potential benefits from increased loans by the public sector are negated by offsetting decreases in private sector credit.

The important independent role of bank loans in determining activity points to the fact that banking strains may have undermined the monetary transmission mechanism over the last few years. To the extent that banks have responded to their own difficulties by reducing their loans to the private sector, such behavior will have tended to offset the benefits of monetary easing. Indeed, the historical decomposition of the summary VAR shows that, while unanticipated monetary loosening has had a positive effect on business investment recently, shocks to bank loans have dragged down business investment, especially since 1996. We argue that bank weaknesses explain a large part of the negative shocks to bank loans.

Looking to the future, the increasing role of private securities markets in financial intermediation likely to be created by the Big Bang financial deregulation initiative may well reduce the central role of banks in Japan's financial system, although such changes are likely to be gradual rather than rapid, particularly given the importance of small companies in Japan's industrial structure. In the meantime, the results from this paper suggest that restoring the banking system to full health should be an important component of any strategy to support activity through monetary policy.

\section{APPENDIX I Data Sources}

Aggregate demand: Economic Planning Agency, Annual Report on National Accounts.

Consumer price index, broad money, base money, bank loans, bank holdings of securities, overnight call rate, average lending rate on new bank loans: Bank of Japan, Economic Statistics Monthly.

Corporate and household funding: Bank of Japan, Flow of Funds Accounts, Economic Statistics Monthly.

Bank strength: Tokyo Stock Exchange (First Section) banking sector index divided by composite index (TOPIX). 


\section{APPENDIX II \\ Impulse Response Functions of Models}

Figure A1. Japan: Impulse Response Functions for the Basic Model (Response to One S.D. Innovations \pm 2 S.E.)

$\begin{array}{ll}\mathrm{YP}=\text { Private demand } & \mathrm{CPI}=\text { Consumer price index } \\ \mathrm{OCR}=\text { Overnight call rate } & \mathrm{M} 2=\text { Broad money }\end{array}$
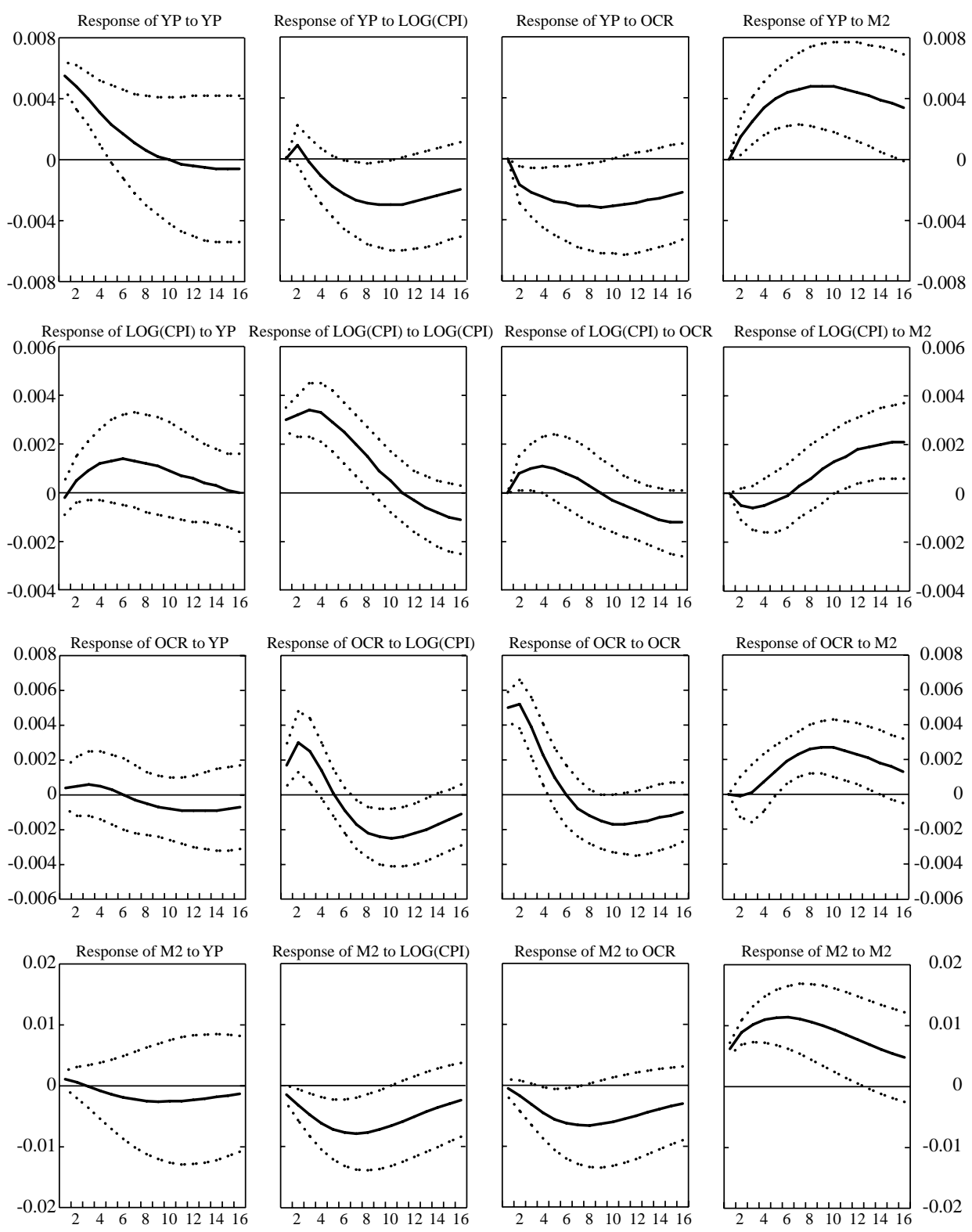
Figure A2. Japan: Impulse Response Functions for the Private Sector Funding Model

(Response to One S.D. Innovations \pm 2 S.E.)

$\mathrm{YP}=$ Private demand $\quad \mathrm{CPI}=$ Consumer price index $\quad \mathrm{OCR}=$ Overnight call rate $\quad \mathrm{M} 2=$ Broad mone

$\mathrm{PGFI}=\mathrm{L}$ Lans from government financial institutions $\quad \mathrm{CM}=$ Capital market financing $\quad \mathrm{PBKPV}=$ Loans from private banks
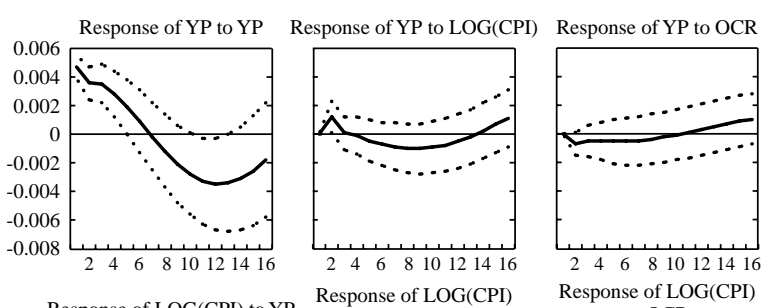

Response of YP to M2 Response of YP to PGH
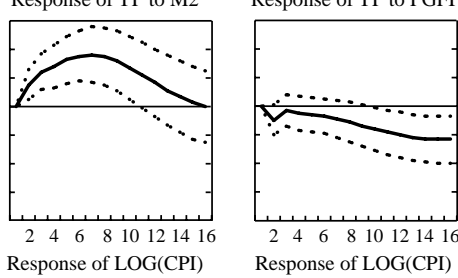

Response of LOG(CPI) to YP Response of LOG(CPI)

Response of $\mathrm{LOG}(\mathrm{CP})$

Response of $\mathrm{LOG}(\mathrm{CP})$
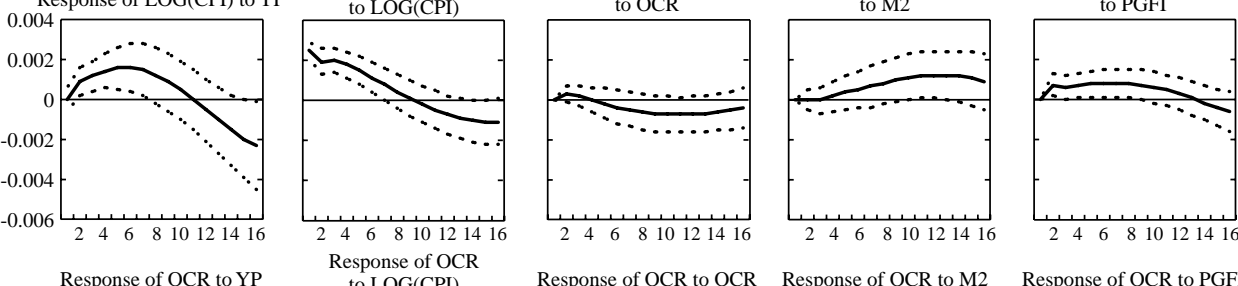

Response of OCR to OCR

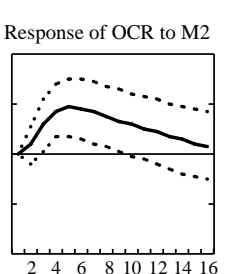

$246 \begin{array}{lllll}2 & 610121416\end{array}$
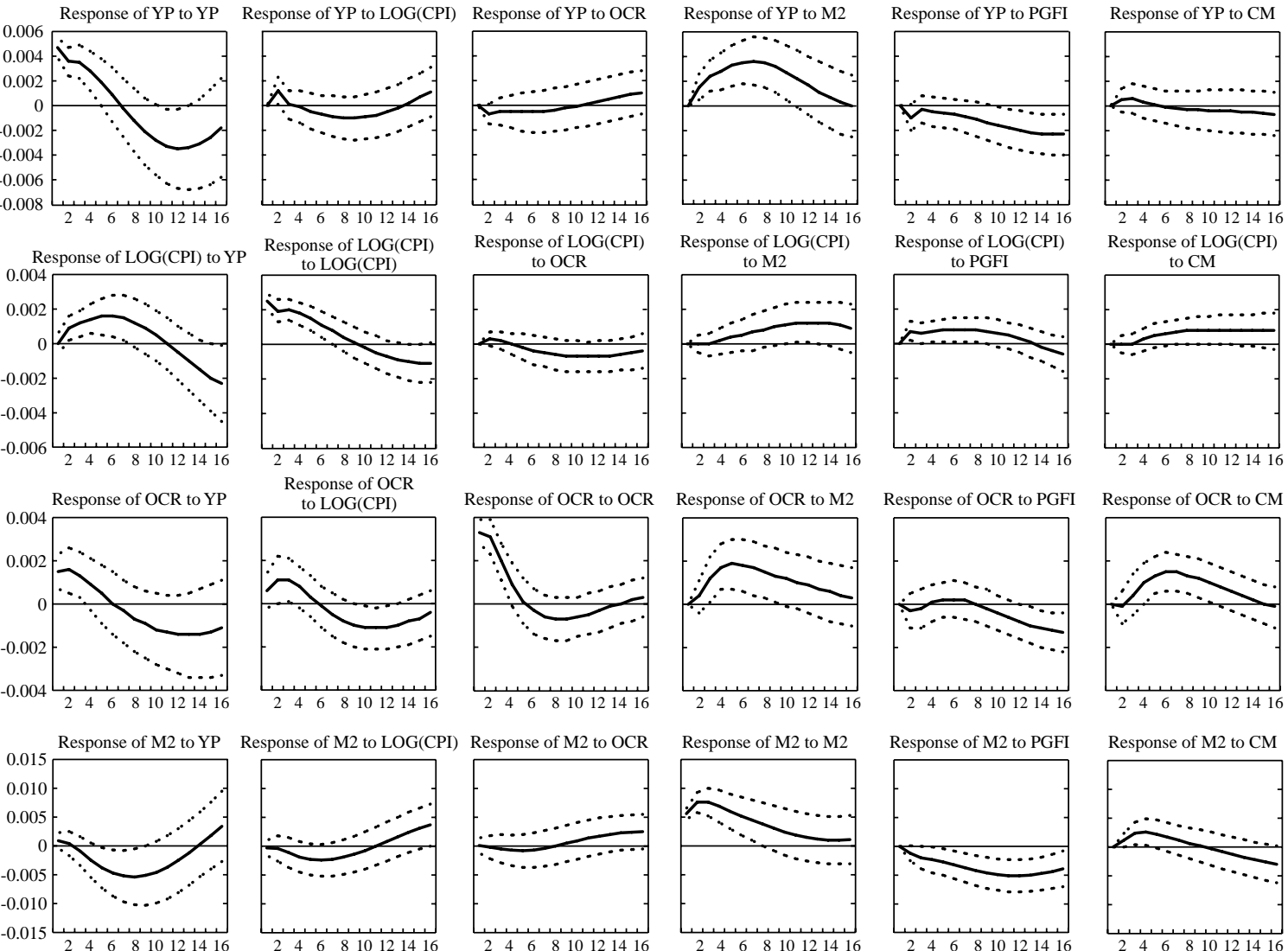

$\frac{1+16114}{246810121416}$
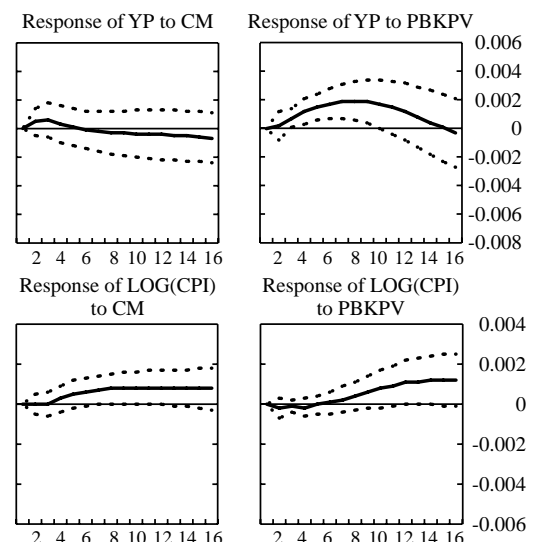

$\frac{1+1610.14}{2468810121416}-0.008$

Response of LOG(CPI)
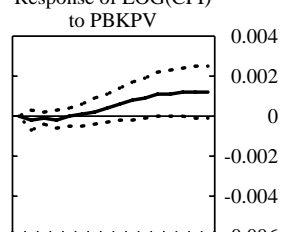

Response of OCR to CM Response of OCR to PBKPV 0.004
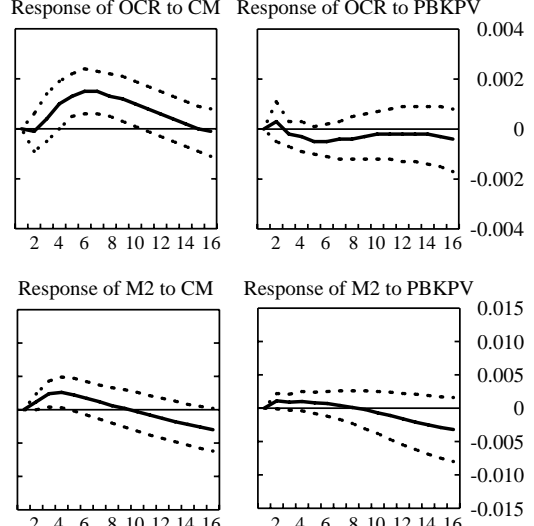

$\frac{1 \mathrm{~W}}{246810121416}-0.015$ 


\section{Figure A2. (concluded)}

(Response to One S.D. Innovations \pm 2 S.E.)

$\mathrm{YP}=$ Private demand $\mathrm{CPI}=$ Consumer price index $\quad \mathrm{OCR}=$ Overnight call rate $\quad \mathrm{M} 2=\mathrm{Broad}$ money

PGFI = Loans from government financial institutions $\quad \mathrm{CM}=$ Capital market financing $\quad \mathrm{PBKPV}=$ Loans from private banks
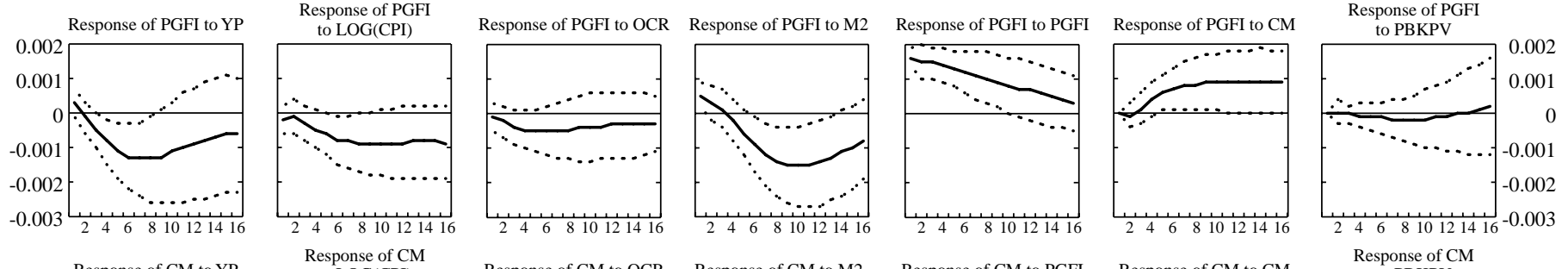
0.002
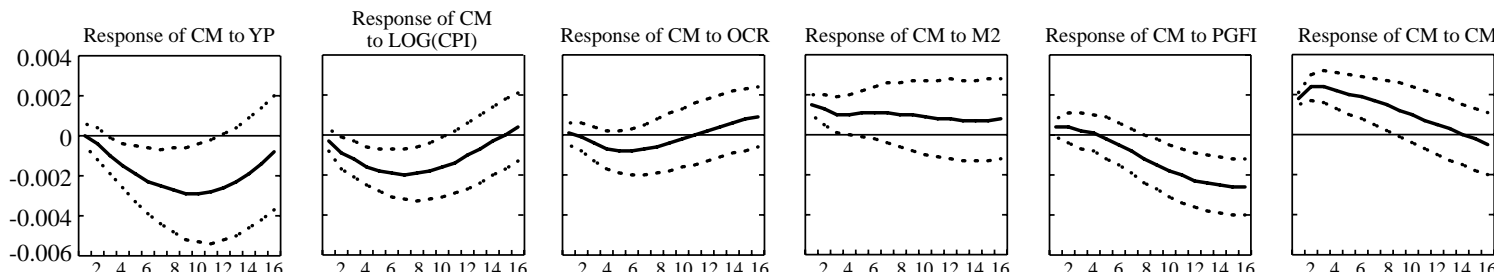

$$
\begin{gathered}
\text { Response of CM } \\
\text { to PBKPV }
\end{gathered}
$$
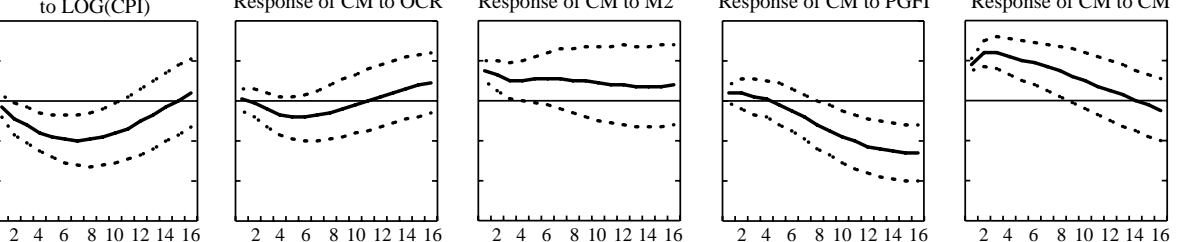

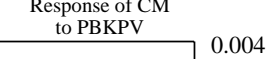

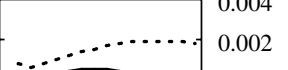

0

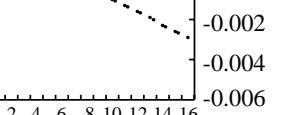

Response of PBKPV

Response of PBKPV to M2

Response

Response of PBKPV to CM

Respons

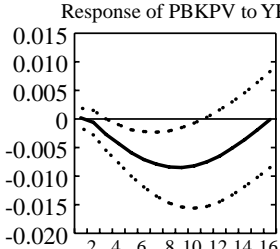

Response of PBKPV
to LOG(CPI)
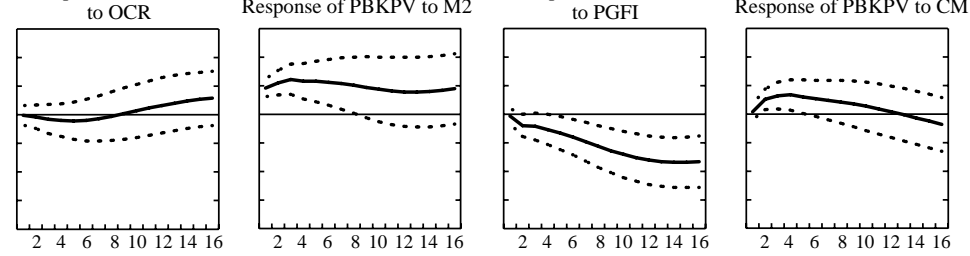

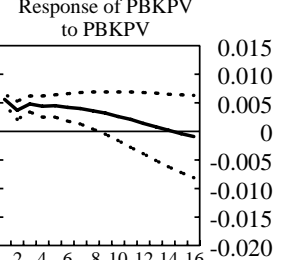


Figure A3. Japan: Impulse Response Functions for the Bank Lending Model (Response to One S.D. Innovations \pm 2 S.E.)

$\mathrm{YP}=$ Private demand $\mathrm{CPI}=$ Consumer price index $\quad \mathrm{OCR}=$ Overnight call rate $\quad \mathrm{M} 2=$ Broad money

LOAN $=$ Bank loans $\quad$ SEC $=$ Banks' holdings of securities
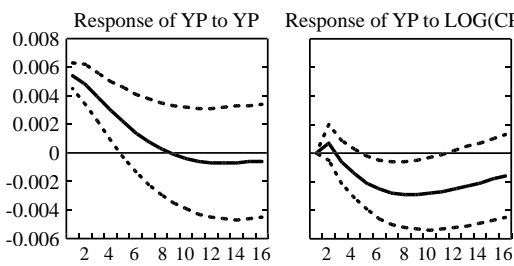

Respor Response of $\mathrm{LOG}(\mathrm{CP})$
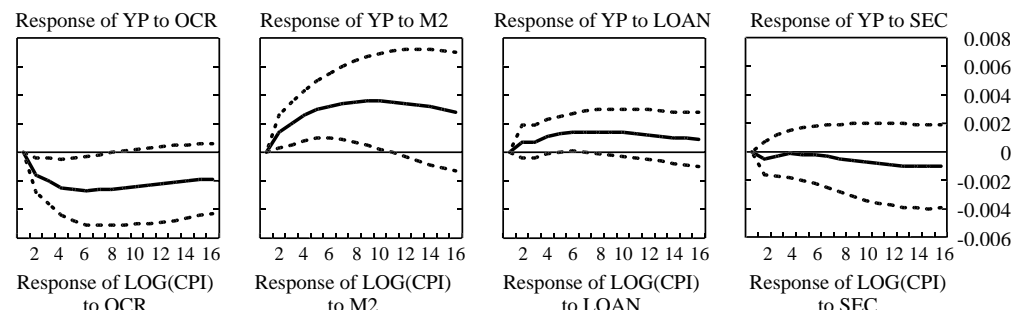

$2468810121416-0.006$

Response of $\mathrm{LOG}(\mathrm{CPI})$

Response of LOG(CPI)

Response of $\mathrm{LOG}(\mathrm{CPI})$
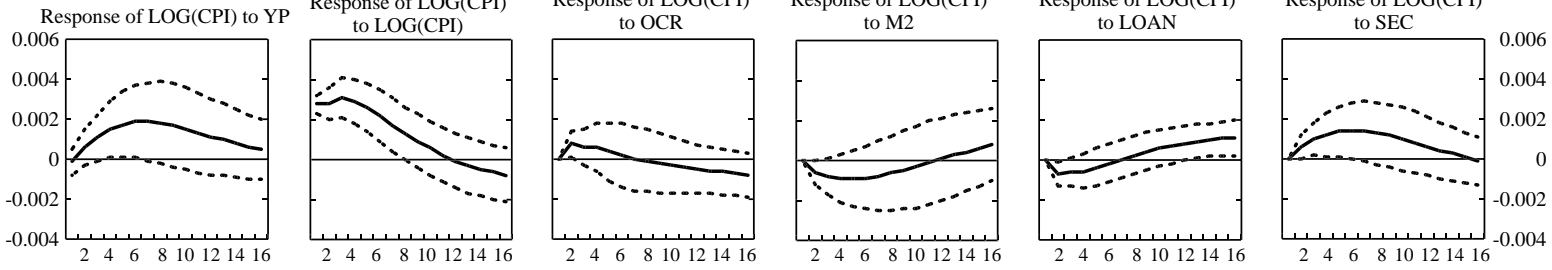

Response of OCR
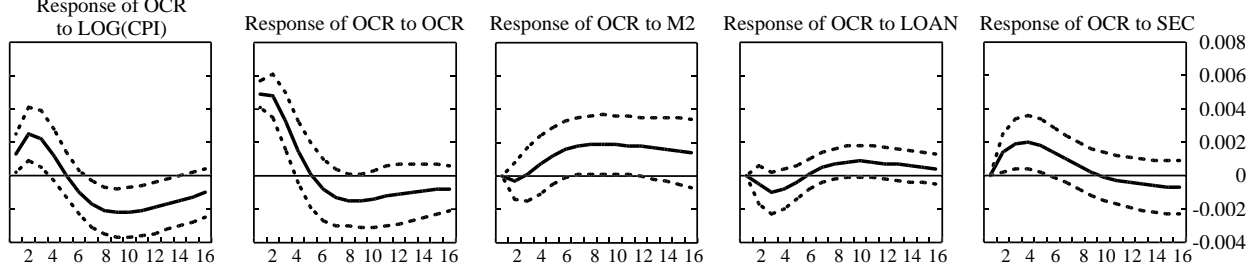

246810121416

$\frac{1.111116}{246810121416}$

4

246810121416 
Figure A3. (concluded)

(Response to One S.D. Innovations \pm 2 S.E.)

$\mathrm{YP}=$ Private demand $\mathrm{CPI}=$ Consumer price index $\quad \mathrm{OCR}=$ Overnight call rate $\quad \mathrm{M} 2=$ Broad money LOAN $=$ Bank loans $\quad$ SEC $=$ Banks' holdings of securities

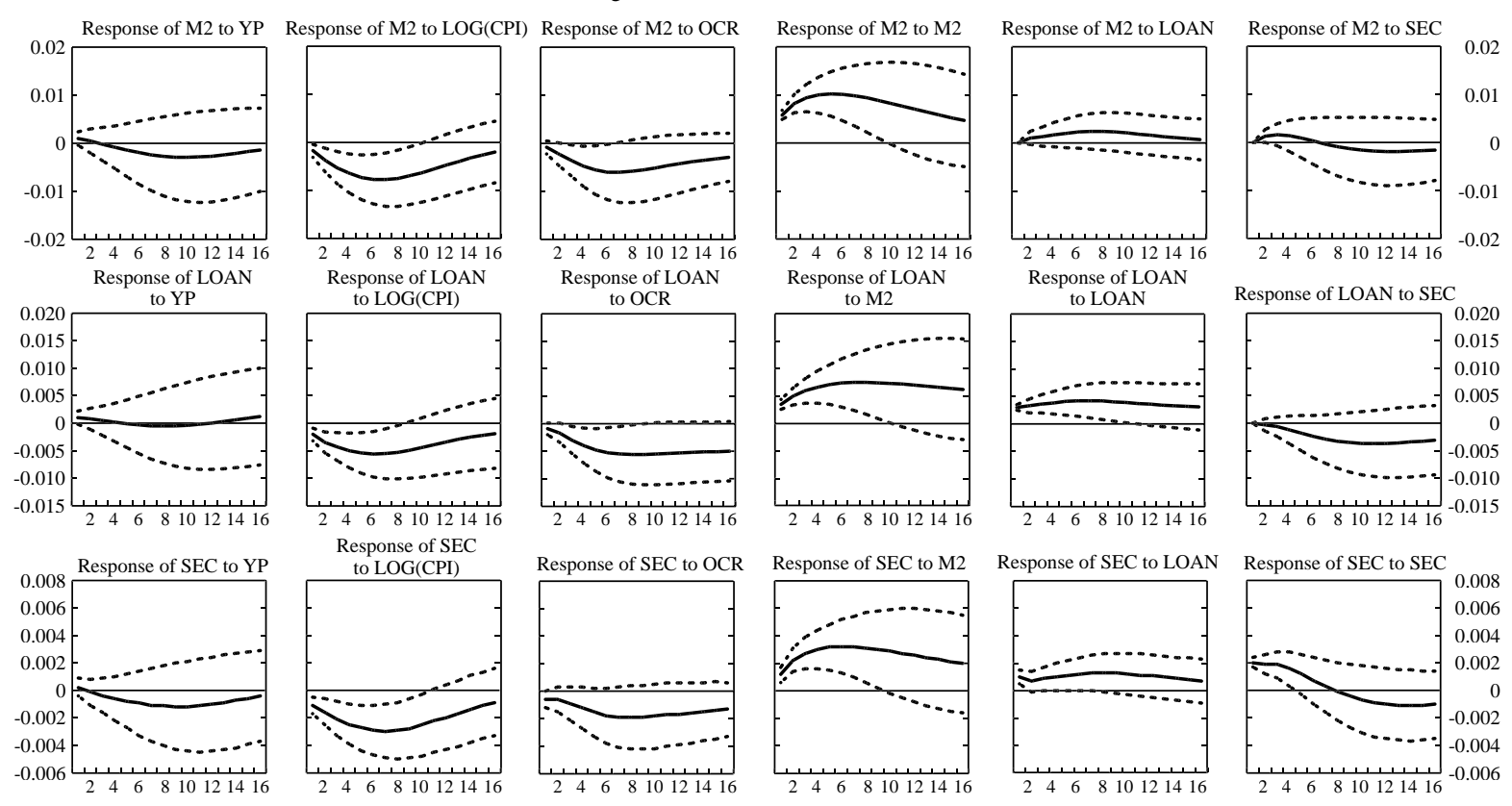


Figure A4. Japan: Impulse Response Functions for the Summary Model (Response to One S.D. Innovations \pm 2 S.E.)

YP-BI $=$ Private demand minus business investment $\mathrm{BI}=$ Business investment $\quad \mathrm{CPI}=$ Consumer price inde OCR $=$ Overnight call rate $\quad \mathrm{M} 2=$ Broad money $\quad$ LOAN $=$ Bank loan

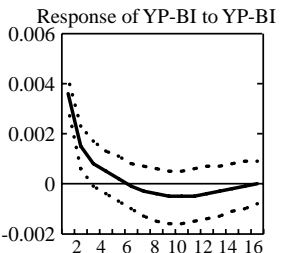

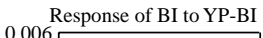

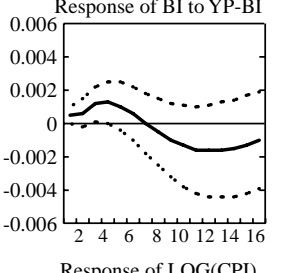

Response of LOG(CPI)

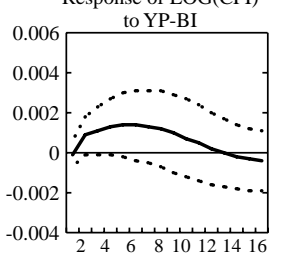

$\frac{1}{246810121416}$
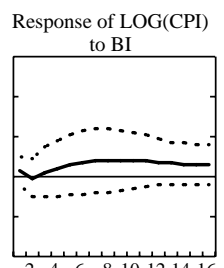

246810121416 to $\mathrm{LOG}(\mathrm{CPI})$

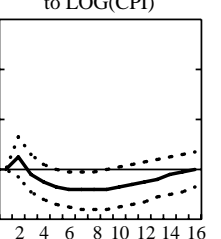

01214

Response of BI
to LOG(CPI)

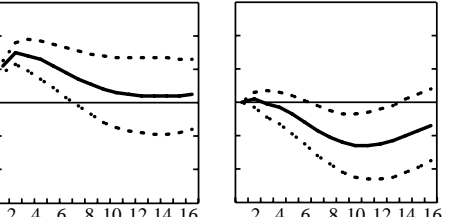

101214

Response of $\mathrm{LOG}(\mathrm{C}$

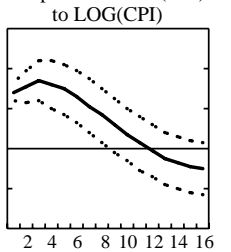

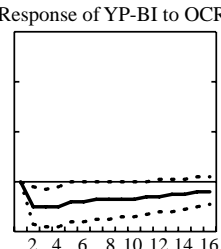

121416

Response of BI to OCR

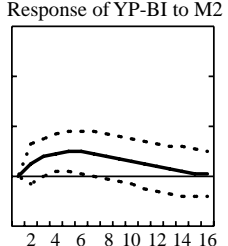

$\begin{array}{lllllll}4 & 6 & 8 & 10121416\end{array}$

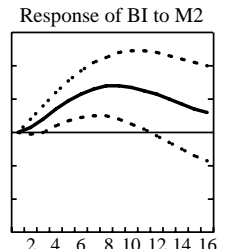

$\frac{14111016}{246810121416}$

Response of $\mathrm{LOG}(\mathrm{CPI})$
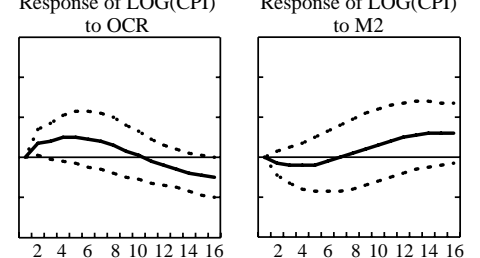

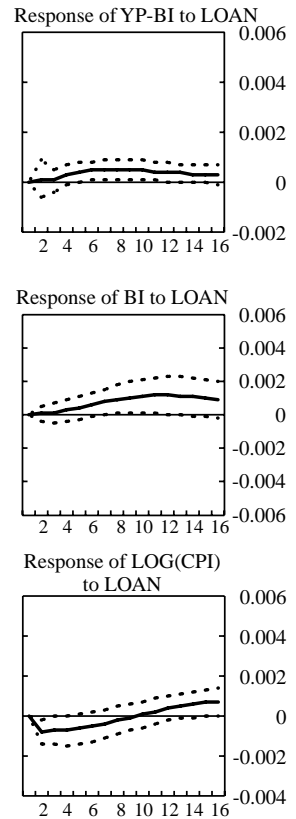

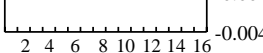


Figure A4. (concluded)

(Response to One S.D. Innovations \pm 2 S.E.)

$\mathrm{YP}-\mathrm{BI}=$ Private demand minus business investment $\mathrm{BI}=$ Business investment $\quad \mathrm{CPI}=$ Consumer price index $\mathrm{OCR}=$ Overnight call rate $\quad \mathrm{M} 2=$ Broad money $\quad$ LOAN $=$ Bank loans
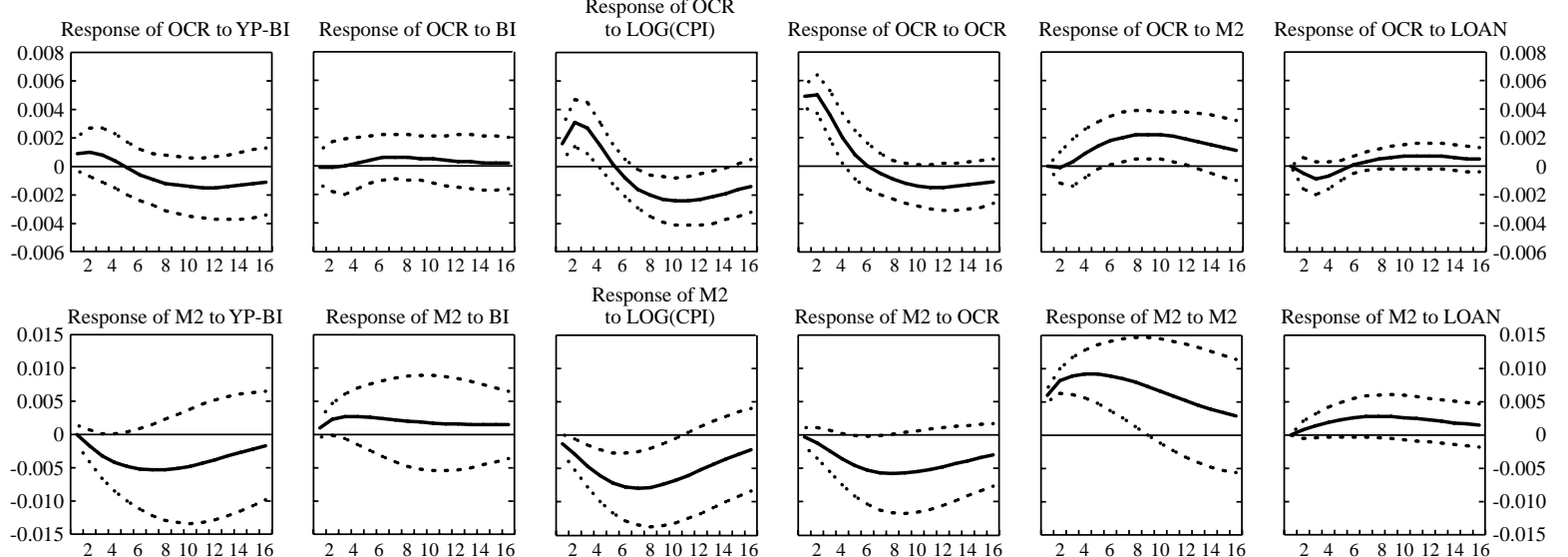

Response of M2
to LOG(CPI)
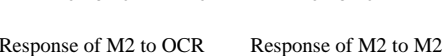

2446810121416
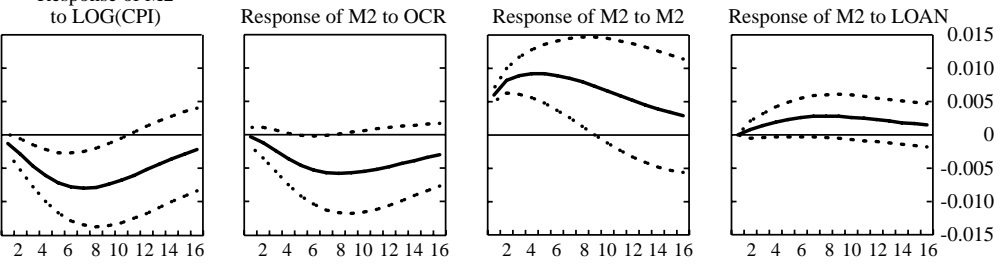

Response of LOAN to YP-BI Response of LOAN to BI

Response of LOAN
to LOG(CPI)
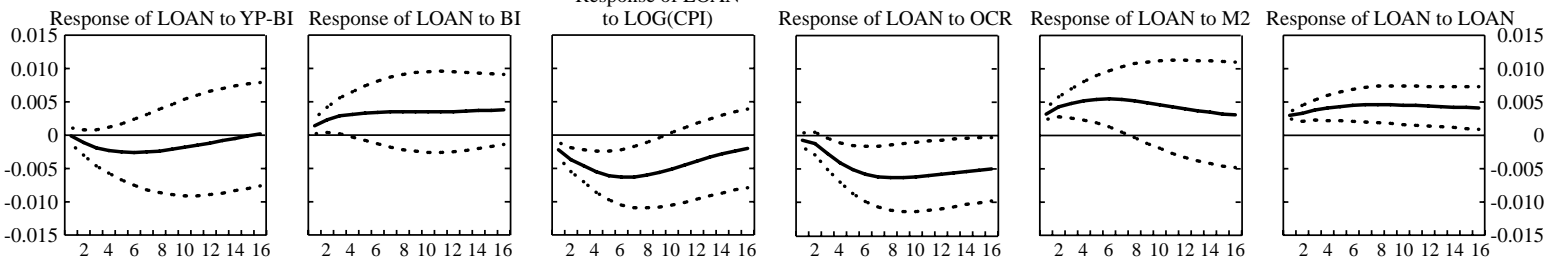


\section{APPENDIX III \\ Exogenizing a Variable}

Consider the three-variable VAR:

$$
\begin{aligned}
& x_{t}=\alpha_{1} x_{t-1}+\beta_{1} y_{t-1}+\gamma_{1} z_{t-1} \\
& y_{t}=\alpha_{2} x_{t-1}+\beta_{2} y_{t-1}+\gamma_{2} z_{t-1} \\
& z_{t}=\alpha_{3} x_{t-1}+\beta_{3} y_{t-1}+\gamma_{3} z_{t-1}
\end{aligned}
$$

We exogenize the variable $z$ by running a two-variable VAR with $z$ as an exogenous variable:

$$
\begin{aligned}
& x_{t}=\alpha_{1} x_{t-1}+\beta_{1} y_{t-1}+\gamma_{1} z_{t-1} \\
& y_{t}=\alpha_{2} x_{t-1}+\beta_{2} y_{t-1}+\gamma_{2} z_{t-1}
\end{aligned}
$$

This procedure generates a VAR in which the first two equations are identical to the original VAR. However, the impulse response functions will be different because any interaction between these variables that passes through $z$ will be blocked (because it is exogenous). Hence, comparisons of the two sets of impulse response functions provides a measure of the importance of the variable $z$ in the transmission mechanism.

\section{REFERENCES}

Aghevli, Bijan B., Tamim Bayoumi, and Guy Meredith, eds., 1998, Structural Change in Japan: Macroeconomic Impact and Policy Challenges (Washington: International Monetary Fund).

Bayoumi, Tamim, 1999, "The Morning After: Explaining the Slowdown in Japanese Growth in the 1990s," IMF Working Paper No. WP/99/13 (Washington: International Monetary Fund).

Bernanke, Ben S., and Alan S. Blinder, 1992, "The Federal Funds Rate and the Channels of Monetary Transmission," American Economic Review, Vol. 82 (September), pp. 901-21.

Bernanke, Ben S., and Mark Gertler, 1995, "Inside the Black Box: The Credit Channel of Monetary Policy Transmission," Journal of Economic Perspectives, Vol. 9 (Fall), pp. 27-28.

Christiano, Lawrence J., Martin Eichenbaum, and Charles Evans, 1996, "The Effects of Monetary Policy Shocks: Evidence from the Flow of Funds," Review of Economics and Statistics, Vol. 78 (February), pp. 16-34.

_ 1999, "Monetary Policy Shocks: What Have We Learned and To What End?" in Handbook of Macroeconomics, ed. by John B. Taylor and Michael Woodford (Amsterdam: Elsevier).

Gibson, Michael, 1995, “Can Bank Health Affect Investment? Evidence from Japan,” Journal of Business, Vol. 68 (July), pp. 281-308.

Hamilton, James D., 1994, Time Series Analysis (Princeton: Princeton University Press).

Ito, Takatoshi, and Yuri Nagataki Sasaki, 1998, "Impacts of the Basle Capital Standard on Japanese Banks' Behavior," NBER Working Paper No. 6730 (Cambridge, Massachusetts: National Bureau of Economic Research).

Kasa, Ken, and Helen Popper, 1997, "Monetary Policy in Japan: A Structural VAR Analysis" Journal of the Japanese and International Economies, Vol. 11, No. 3, pp. 275-95. 


\section{A PEEK INSIDE THE BLACK BOX}

Kashyap, Anil K., and Jeremy C. Stein, 1997, "What Do a Million Observations on Banks Say About the Transmission of Monetary Policy?" NBER Working Paper No. 6065 (Cambridge, Massachusetts: National Bureau of Economic Research).

Krugman, Paul R., 1998, "It's Baaack: Japan's Slump and the Return of the Liquidity Trap," Brookings Papers on Economic Activity: 2, Brookings Institution pp. 137-205.

Kwon, Eunkyung, 1998, "Monetary Policy, Land Prices, and Collateral Effects on Economic Fluctuations: Evidence from Japan," Journal of the Japanese and International Economies, Vol. 12.

Leeper, Eric M., Christopher A. Sims, and Tao Zha, 1996, "What Does Monetary Policy Do?" Brookings Papers on Economic Activity: 2, Brookings Institution pp.1-78.

Lipworth, Gabrielle, and Guy Meredith, 1998, "A Reexamination of Indicators of Monetary Policy and Financial Conditions," in Structural Change in Japan, ed. by Bijan B. Aghevli, Tamim Bayoumi, and Guy Meredith (Washington: International Monetary Fund).

Mishkin, Frederick, 1995, "Symposium on the Monetary Transmission Mechanism," Journal of Economics Perspective, Vol. 9 (Fall), pp. 3-10.

Ogawa, Kazuo, 1999, "Monetary Policy, Credit, and Real Activity: Evidence from the Balance Sheets of Japanese Firms," paper prepared for the NBER Japan Project meeting in Palo Alto.

Okina, Kunio, 1993, “Market Operations in Japan: Theory and Practice,” in Japanese Monetary Policy, ed. by Kenneth J. Singleton (Chicago: University of Chicago Press).

Ramaswamy, Ramana, and Christel Rendu, 1999, “Japan's Stagnant Nineties: A Vector Autoregression Perspective," IMF Working Paper No. WP/99/45 (Washington: International Monetary Fund).

Sekine, Toshitaka, 1999, "Firm Investment and Balance-Sheet Problems in Japan," IMF Working Paper No. WP/99/111 (Washington: International Monetary Fund).

Sims, Christopher A., 1992, "Interpreting the Macroeconomic Time Series Facts: The Effects of Monetary Policy," European Economic Review, Vol. 36, No. 5, pp. 875-1011.

Singleton, Kenneth J., ed., 1993, Japanese Monetary Policy (Chicago: University of Chicago Press).

Ueda, Kazuo, 1993, “A Comparative Perspective on Japanese Monetary Policy: Short-Term Monetary Control and the Transmission Mechanism," in Japanese Monetary Policy, ed. by Kenneth J. Singleton (Chicago: University of Chicago Press).

Woo, David, 1999, "In Search of Capital Crunch: Supply Factors Behind the Credit Slowdown in Japan,” IMF Working Paper No. WP/99/3 (Washington: International Monetary Fund). 